Historic, Archive Document

Do not assume content reflects current scientific knowledge, policies, or practices. 

NOV I \&

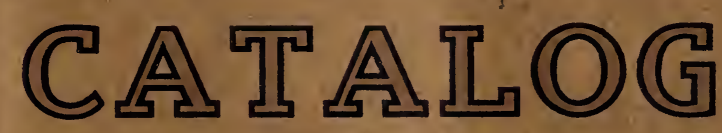
AND

\section{Planter"s MIanயa!}

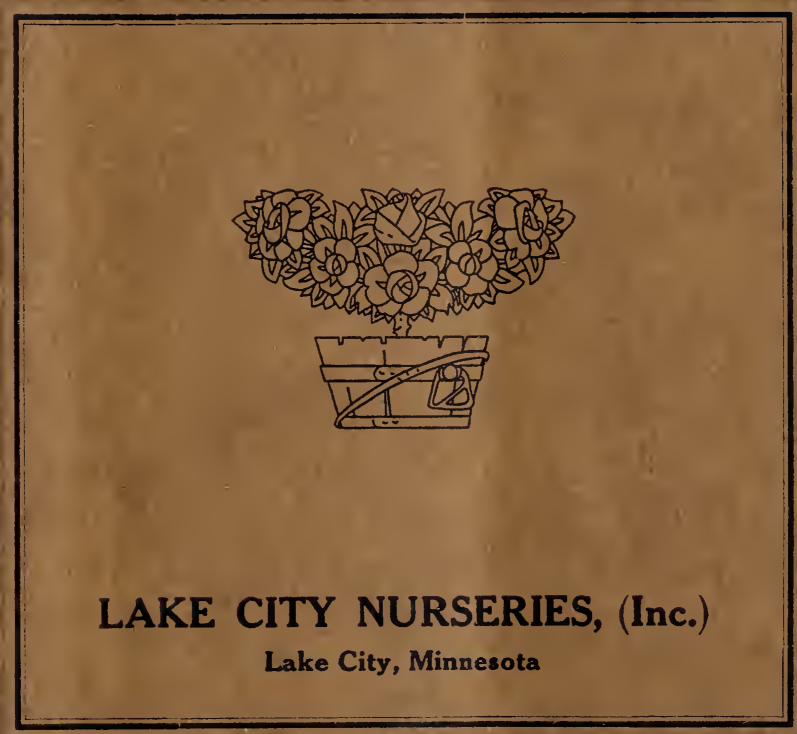




\section{INDEX}

Page

Introductory

3 Rhubarb

Page

General Information

5 Strawberry-Raspberry

30

Spray Program

Landscape Gardening 31

Orchard Planting

Orchard Plan

Perennials

Apples

Phlox

Peonies

Apples (Perkins Seedlings) .... 15

Apples (Crabs)

Bulbs, for Fall Planting 38

Plums 17

Cherries Bulbs, for Spring Planting

Grapes 19 22

Gooseberries 23

Currants 24

Raspberries

Iris

Lilies 41

Blackberries

Roses 43

Climbing Vines 44

Flowering Shrubs 45 25

27

Ornamental Hedges

Strawberries 28

Asparagus 29

Horse Radish 30 Shade and Ornamental Trees - 56 Nut Trees Forest Tree Seedlings 59 Evergreens 60 61 


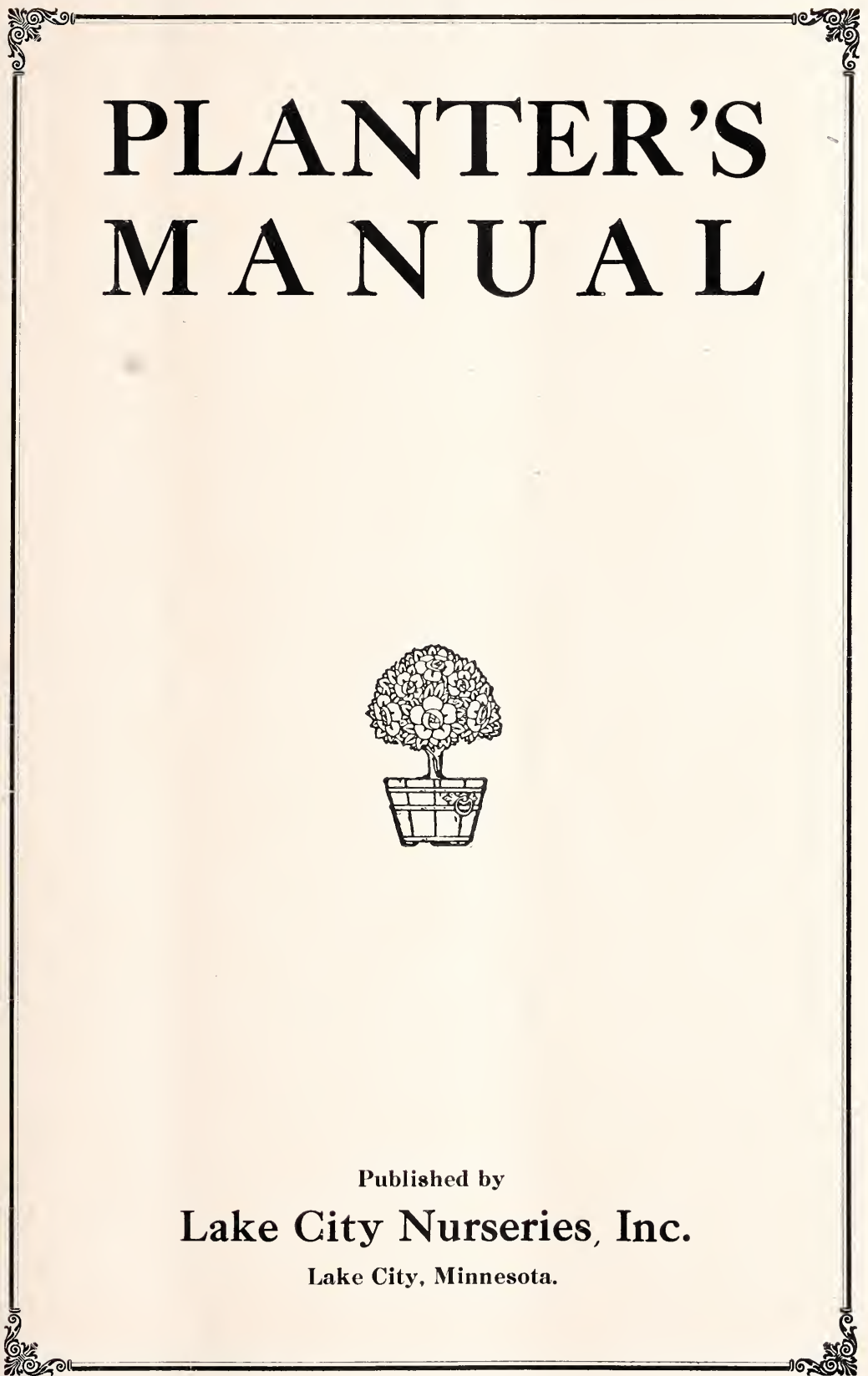


OUR SLOGAN:

"Trees that Grow"

"Service that Pleases" 


\section{LAKE CITY NURSERIES, Inc.}

\section{OFFICERS}

Bj. Loss, President

A. O. Stubstad, Vice-president

G. V. Erickson, Secretary

M. L. Erickson, Treasurer

\section{Introductory}

\section{Location}

The nurseries are located within the city limits of Lake City, Minnesota, on the banks of Lake Pepin, adjoining the right-of-way of the Chicago, Milwaukee Railway. Paved Highway No. 3 parallels the nursery about one block away, between it and Lake Pepin. Lake City is about 60 miles southeast of St. Paul.

Soil

The soil in the nurseries is wonderfully well adapted to the growing of nursery stock; rich and loamy. of our trees and shrubs.

It is this soil which gives the remarkable root system

Acreage

History

The nursery consists of 110 acres of land, every foot of which is tillable.

The business is a continuation, on a larger scale, of a small but excellent nursery which was established in 1906 by Mr. G. A. Tolleson. On account of ill health, Mr. Tolleson found it necessary to leave Minnesota, and sold his nursery to us in the fall of 1921. The following year we had the good fortune to buy a considerable acreage of valuable land adjoining that we already owned.

Management

Every business reflects its management in its success and the satisfaction given its customers. Nothing can take the place of actual experience. The owners of this nursery have had nearly twenty years of practical experience in the business. Individually their experience has been different. The President has been sales manager and salesman for a number of years, while the Vice-president has spent much of his life in the propagation of nursery stock. As the officers are the owners of the nursery, every order shipped has their personal inspection, and this should mean much to the customer.

Service

Policy customer to become a permanent and steady cus-
tomer. We want to so treat him that he will develop the habit of waiting for our salesman. Only fair treatment, exceptional service and fine stock 
will accomplish this. The owners of this nursery are on the job all the time. They know good stock; grow it and are believers in good service. Every customer has their personal attention, and satisfaction will be assured.

What We Grow Only the best varieties adapted to this climate are grown in the nursery. Quality, rather than quantity is sought for. Our apple trees are propagated from a famous prize winning orchard in Minnesota; healthy bearing trees under expert care. Our new plums are propagated from stock direct from originator, insuring correct labeling. Our ornamental line is most complete and covers varieties of shrubs, trees, vines and evergreens that are suitable for this climate. Our motto, "Trees That Grow," and "Service That Pleases," we have tried to build into the trees and plants which we send out, and in their service to our prospective planter, they will reflect the painstaking care which we give our stock before it leaves our place. Our line is very complete.

Our Guarantee To err is human, but we offer, upon full proof of error, in varieties, to refund original purchase price, or a shipment equal to twice the original shipment. We accept full responsibility for stock we ship, except damage resulting from weather conditions or delay in transit. The customer is judge and jury. His verdict is final with us. People are fair if fairly dealt with. That is our business of building up a business. How does it appeal to you?

Yours very truly,

THE LAKE CITY NURSERIES, INC.

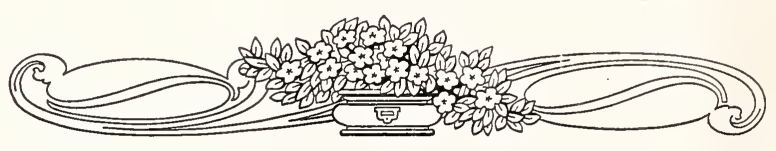

\section{General Information}

\section{Where}

to Plant
As a rule any well drained land suited to farm and garden crops will prove satisfactory for the general planting of trees and shrubs in the Northwest. The laying out of a grove or orchard, where a landscape gardener is not employed, should be done with care and it is always well to draw a complete diagram before planting is started. Many people have made the mistake of planting their outside groves or wind break too close to the buildings, making it impossible to get the best results from inside planting later on. If planting a wind break, be sure 
to go back far enough for orchard, garden and shrubbery to be planted inside without being crowded and to allow for a free and plentiful circulation of air on the inside. Fruit trees, being expected to grow and produce fruit at the same time, should be planted on land that is fairly rich and which has been well cultivated and drained. Where possible it is better to plant apple and plum orchards on a north or east slope. A southern slope is the least desirable owing to the fact that the sun brings the frost out of the ground earlier in the spring and freezing and thawing of the ground at the trunk is very liable to cause damage to the roots. However, where no other place is available this can be overcome $\mathrm{b}$ a heavy mulch as described later on.

\section{How}

to Plant
It is always best to dig the holes as the trees are planted. This will prevent the earth that is thrown out and the bottom of the hole from being dried out by the sun and wind and give the roots the natural moisture of the ground which is very essential to young trees. Wherever possible, the ground should be plowed and thoroughly worked up and allowed to settle before planting. If necessary to plant in sod the ground should be loosened for a distance of from two to three feet from the tree each way according to the size. Dig the holes large

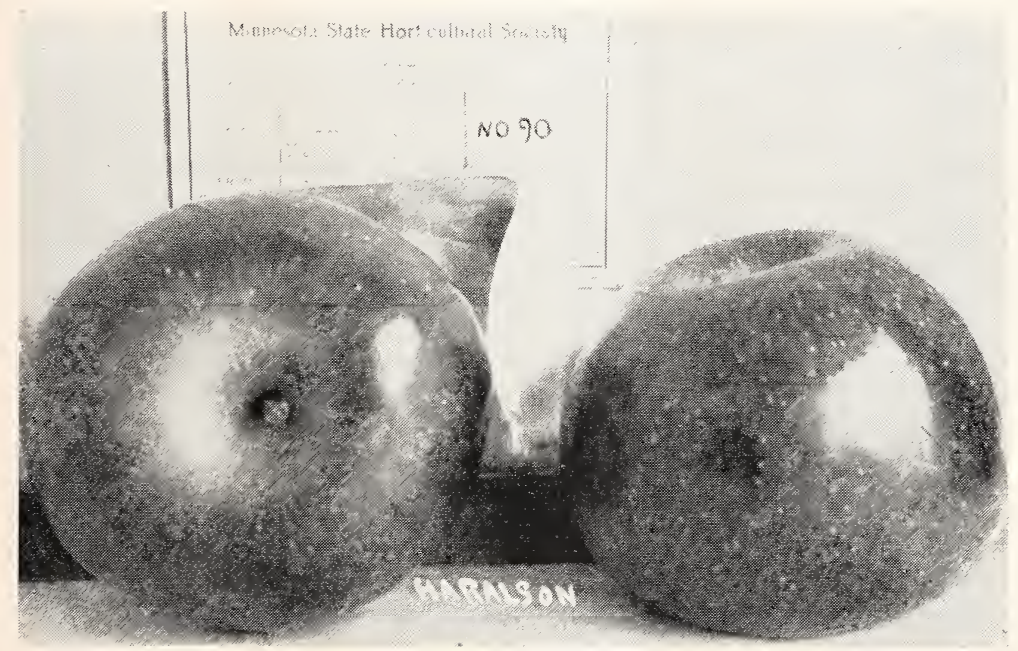

Haralson Apple

Galesville, Wis., April 20th, 1925.

Gentlemen: Enclosed find check for the amount of McIntosh trees you sent me. We certainly are pleased with them as they are a fine lot, and I will recommend any one who wants to deal with you. We did not open the bundle until a few days ago and that is the reason we did not send the check sooner.

(Signed) W. D. YOUNG \& SONS. 
enough to allow the roots to be layed in without bending and deep enough for the roots to be covered a few inches deeper than they were in the nursery row. If the trench where trees are healed in is any distance from the place they are to be planted, it is well to uncover a few at a time and place them in a pail of mud. In that way they can be carried to the field and taken out one at a time without being exposed.

\section{When}

to Plant

In Minnesota and the Dakotas the proper time to plant trees or shrubs is in April or May, according to the season. Hardy perennials do well when planted in the fall but they also succeed well when planted in the spring. Tulips, Narcissi, Hyacinths and the Dutch bulbs can only be planted in the fall, generally in September or October.

Care of Nursery Stock
It is safe to say that seventy-five per cent of the nursery stock that fails to grow, or does grow but is always stunted and weak, is due to improper handling after it is received by the customer. It cannot be impressed too strongly upon planters the necessity of keeping the roots from the sun or wind. When the stock is received, open the bundle in the shade out of the wind and if you are not ready to
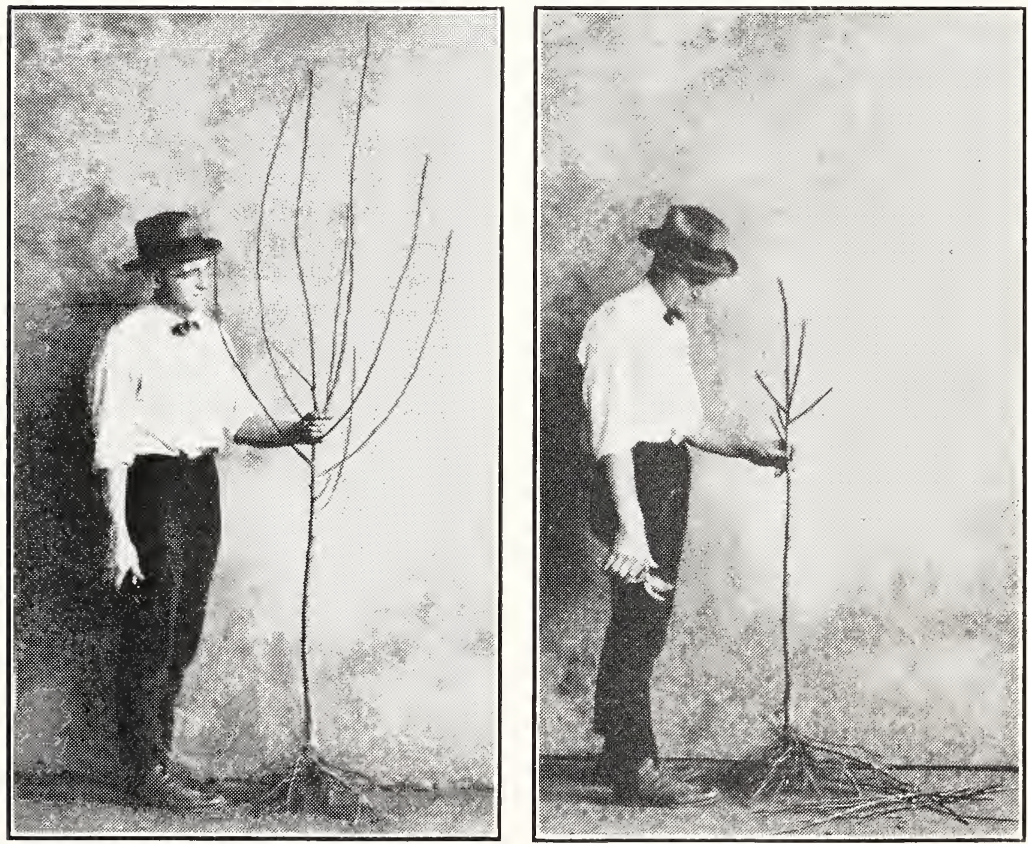

Before and after pruning. Don't be afraid to cut trees back before planting. See pruning instructions. 
plant immediately, heal the roots in the ground, soaking them well as you do. If well healed in they can be kept without damage for a reasonable time. However, the sooner trees are set in their permanent place after being opened the better.

\section{Pack Dirt}

Firmly

As the trees are placed in the hole with $\mathrm{th}$ e roots carefully spread out, pull in the earth a little at a time and pack it firmly with the hands until there is enough to prevent bruising the roots when stamping it with the foot. Fill the hole up, packing the earth as firmly as possible as you go. Finish with a little loose dirt and allow the ground to slope toward the tree to collect moisture.

\section{Pruning is Essential}

\section{and judgement. If toone with care} and judgment. If too much wood is left above the ground the roots will not be able to supply it with moisture and the consequences will be a serious set-back or possible failure. Use a sharp knife or pruning shears and cut away all bruised or broken roots. On fruit trees, the stems should now be put in condition for the formation of the top by removing all the limbs to the point where it is desired to

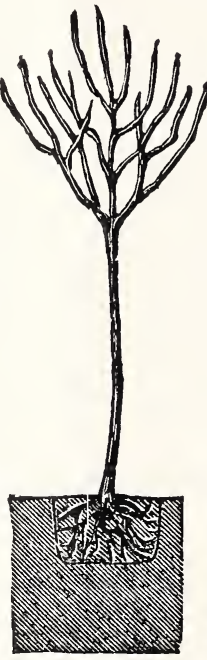

Wrong Way

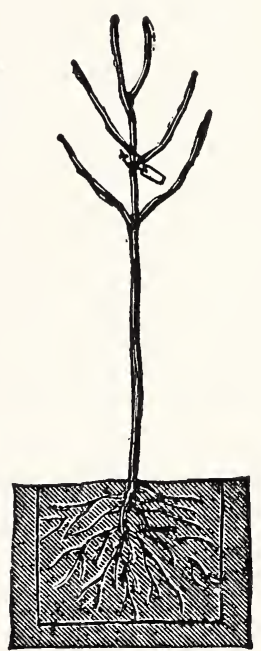

Right Way

Be sure to dig holes large enough to allow the roots to lay well spread out.

have the top; then cut back each remaining limb, leaving from four to six buds of last season's growth. In the absence of any limbs suitable to form a top, cut the trees down to the requisite height, leaving the dormant buds to make the top. Pruning vigorously at time of setting is generally very distasteful to the planter, as it injures for a time the appearance of the tree to an unpracticed eye. It should, however, be unhesitatingly performed; all the branches to the extent of at least onehalf the length of the previous year's growth being removed. Care should also be used to give the proper form to the tree. The head may be left high or low, as the taste of the planter may prefer, or as the nature of the tree in some cases may require. Large shade trees should be cut down to about two-thirds their height and all or nearly all of the branches removed, leaving the naked stem to form a new head. It is a good idea to wrap the lower half of the trees with burlap to protect them from sun scald until the branches are large enough to shade them. In the case of most bush fruits and ornamental shrubs the pruning should be even more severe, leaving but little above the ground. Evergreens are of a different nature and should not be pruned. 
Should be Mulched

Mulching is also a very important matter and all young trees should be well mulched with hay or straw as soon as planted to retain the moisture in the ground around the trunk and also keep down weeds and grass. Never use fresh manure as a mulch at is very liable to damage the tree.

\section{Spraying is Necessary}

Fruit trees and bushes, like other forms of life, cannot do their best while infected by disease or infested with insects. Spraying should be carefully and thoroughly done and at the proper time. Below we give a spraying program that is recornmended by the Department of Agriculture of the State of Minnesota which has been scientifically worked out and can be easily understood and followed.

\section{Spray Program}

The spray mixture for apples and plums best suited to Minnesota conditions is made by adding 5 quarts of liquid commercial lime-sulphur and $1 \frac{1}{2}$ pounds of powdered arsenate of lead to 50 gallons of water. Spraying should always be done under high pressure, 200 pounds or more is better than a lower pressure. Cover every tree thoroughly, and above all be sure to do the spraying at the proper time, as a delay of a few days will greatly reduce the effectiveness of the work.

\section{APPLES}

First Spray: When first flower buds show pink.

Pests controlled-Early stages of leaf eating caterpillars, curculio, scab and codling moth caterpillars.

Second Spray: As soon as petals drop from flowers and before calyx cup closes. Pests controlled-Same as listed under first spray.

Third Spray: Last week of June or first week of July.

Pests controlled-Scab, apple maggot (railroad worm) and leaf eating insects.

Fourth Spray: About July 20.

Pests controlled-Scab, apple maggot (railroad worm) plum curculio and leaf eating insects.

\section{PLUMS}

First Spray: Just before blossoms open. Pests controlled-Curculio, plum pocket, blossom blight, twig blight.

Second Spray: When plums are the size of small peas.

Pests controlled-Curculio and brown rot.

Third Spray: About July 1.

Pests controlled-Curculio and brown rot.
Fourth Spray: When fruit first starts to color.

Pests controlled Curculio and brown rot. Special for Plant Lice. If plant lice are noticed on apples, plums or other plants in early spring, spray with nicotine sulfate, $1 / 2$ pint of 40 per cent nicotine sulfate and 2 or 3 pounds of soap in 50 gallons of water, as soon as discovered. The first lice usually appear just as the buds are bursting. If very numerous when applying regular sprays, nicotine sulfate may be added to regular mixtures. It is more effective when used alone.

\section{CURRANTS AND GOOSEBERRIES}

Spray: Just before buds open. Lime sulphur, one part to nine parts of water. This is a strong solution which is used to destroy the eggs of plant lice, and must not be used after leaves are out.

Pest controlled: Plant lice.

\section{CURRANT WORM}

Spray: Use arsenate of lead at the rate of $1 \frac{1}{2}$ pounds in 50 gallons of water and 4-5-50 Bordeaux mixture as soon as caterpillars are seen. Look for them soon after the leaves are out. If the second brood comes out when the fruit is nearly mature it is safer to use hellebore. May be dusted on leaves in early morning.

\section{CURRANT BORER}

Prune out infested canes before June 1, and burn. Borers usually attack the canes that are two or more years old. It is well to remember in pruning that most of the fruit is borne on the canes that are two years old or older. Do not prune out all old canes each season.

\section{Varieties That As the bulk of our business is done in Northern} Are Hardy

Iowa, Wisconsin, Minnesota, the Dakotas and Montana, it is to our interest to propagate only such varieties of trees, shrubs and plants as are best suited to the soil and climatic conditions of these states. In this book we are listing only such varieties as long experience and rigid tests have proven of value and the planter may feel safe in selecting any of them with a very few exceptions, which will be noted in the descriptions. 


\section{Orchard Planting}

Can Be Made Years ago it was considered impossible to raise to Pay fruit with any degree of success in the Northwest and fruit raising did not meet with any great amount of favor from the early settlers. There were some of the pioneers, however, who had a vision of more and better things for the Northwest and forged ahead with untiring energy. Many were the failures of these early and ambitious fruit fanciers. They soon learned that varieties which did well in the eastern states, where the air is more moist and the growing season longer, were not suited to this section, where the air is dry, the winters long and severe and the summers hot. Today this has all changed. Extensive experiments by individuals and the state and federal governments have brought out fruits of nearly every kind, except tropical fruits, that are not only hardy and bear well but in many cases the fruit is of a better quality than that grown in other parts. A survey made by the State of Minnesota for the five year period from I9I6 to 1920 brought out the fact that orchards that were properly managed and cared for returned a net return per acre far in excess of what could possibly be expected from the ordinary farm crops. In many of the better orchards under survey during this five year period the gross return averaged from three to five hundred dollars per acre. Fruit trees, like all farm crops, produce well or poorly according to the care they receive.

Follow General In setting out an orchard the best methods of plantInstructions ing, pruning, spraying and care are fully covered under "General Information" and if carefully read and followed, the efforts of even the beginner will be crowned with success. Do not lose sight of the fact that even

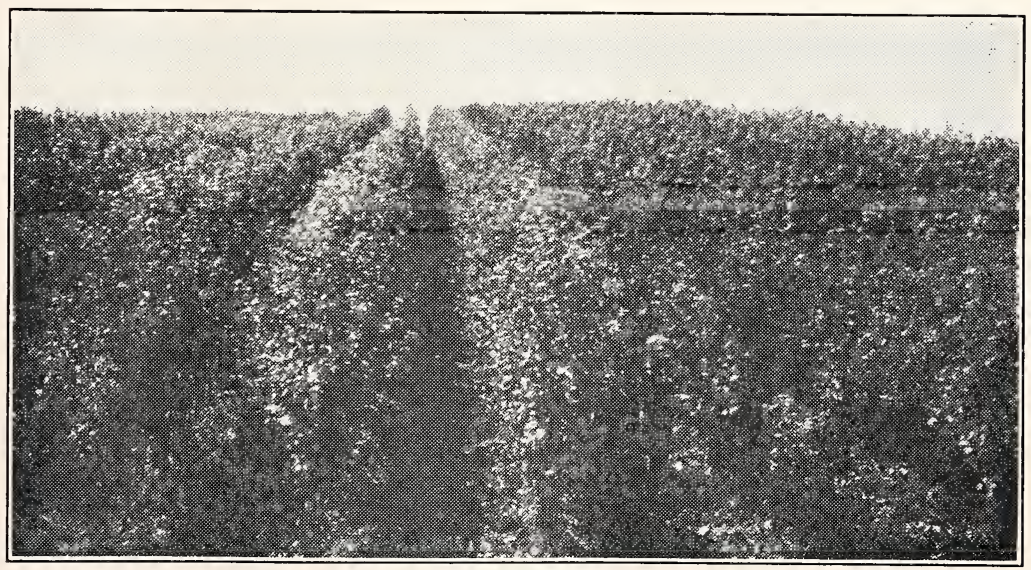

Part of a Forty Acre Block of Apple Trees 
though an orchard is properly planted it must have care to bring the best results.

Laying Out an Orchard The plan given below is very elastic and can be adapted to almost any individual condition. On account of every foot of land being used it will readily recommend itself to the average planter who has a mind to compastness yet ease of cultivation.

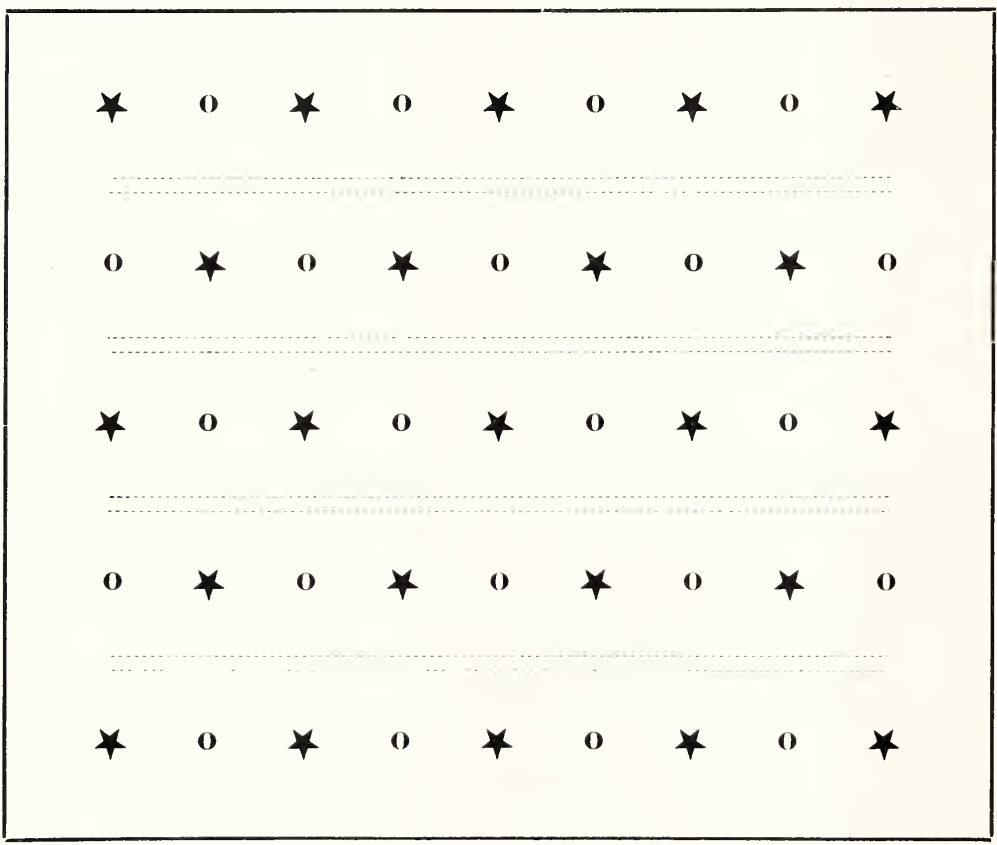

$\star$ Denotes permanent Apple and Crab trees planted 35 feet apart in the row and rows 30 feet apart.

o Denotes fillers, Plums and Cherries 171/2 feet from Apple trees.

Denotes double rows of Small Fruits such as Raspberries, Strawberries, Currants, Gooseberries, etc., between rows of Fruit trees.

\section{After \\ Pruning}

Very much has been said about pruning by various authors. Judging from these and our own experience and observations, we would say: Looking at the health and vigor of a tree, the best time to prune is just before the sap begins to run, early in the spring.

Summer pruning is done to check rank growth and promote fruitfulness. This should be done very cautiously, if at all, as too much 
pruning will harm the tree. When we are in hurry to have a tree bear, we pinch off the bud on the end of the limbs a little in summer. Do not fear to prune the tree when it is young-that is, when it is not growing-and keep pruning as long as it lives.

\section{To Control Blight}

It has been recently discovered that blight may be very effectively controlled by cutting out the blighting twigs as fast as they appear. The cut should be made well below the affected parts and the knife should be sterilized by dipping it in a five per cent solution of carbolic acid after cutting off each twig, so that the disease may not be carried from one limb to another. This work must be done as soon as the disease appears, and carried out persistently. It is also important that neighboring orchards be looked after or the disease will be continually carried back and the work prove unavailing. Birds, bees and other insects are the common carriers of the disease. Some varieties hardly ever blight and this should be remembered when selecting your trees.

\section{To Protect} The Roots

The roots of many trees, especially the apple are more tender than the tops. In winters of scanty snowfall many trees will come thru with enough life in their trunks and branches to open the buds and put forth a few small leaves, but with their roots so seriously injured or killed outright as to ruin the trees. If we always had plenty of snow evenly on the surface, we would never have to think of the roots. But, in order to make them safe in winters with light snowfall, and in places where the snow blows off leaving bare ground, it is always best to cover the ground with a mulch of any convenient material extending from three to six feet out from the trunk of the tree. This does not have to be very thick as it is a matter of common observation that a small amount of litter will keep out a great deal of frost. Where there is litter of any kind about the trees, there will be danger of mice nesting and girdling them, which can be prevented by the use of galvanized screening.

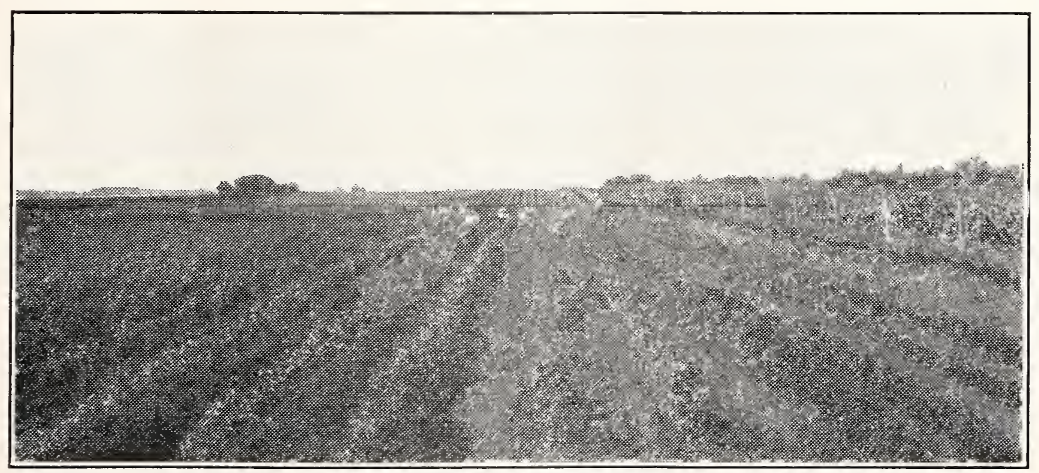


Cultivate The Orchard

There always lias been and probably always will be a conflict of ideas on this question. There are really good points in both methods. In sod the land will stop washing and wasting in heavy rains, and the roots of the apple will be protected by the grass from severe freezing. But, the trees will be much healthier, make a better growth, and stand drought better in cultivated ground. Where the land is level so that it does not wash badly we advise cultivation, with a good mulch put about each tree in November. Where so rolling as to make cultivation impossible, keep the land in clover, and use all the hay as mulch about the trees. In both cases, protect the trees from mice with wire screening. Do not take a crop of hay from the orchard, or allow a hoof of any kind in it.

\section{To Renew an Old Orchard}

There are hundreds of orchards in the country that are not doing their best, that indeed come very near doing their worst, that with a day's work putting them into proper condition to start with, and a few hours each year put into spraying and pruning could be made to produce enough fine fruit for the family and a surplus for the market.

The first thing to do is to cut out the surplus trees. There is no use trying to make apple or plum trees do their best after the branches begin to interlock. When this trouble begins, most people trim out the lower branches that are always the first to touch each other. This is the worst possible policy for it is simply postponing the trouble, and cutting out the most valuable branches of the tree. The second and third sets of branches will soon take their places, and in their turn have to be cut out for the same reason, and so on until there is nothing left of the trees but tufts of branches way up in the air out of reach of spraying machinery, and breaking off with every high wind.

The thing to do is to make a drive on the orchard and cut out every other tree, or every two trees leaving one. There is no more reason for mourning over them than there is over last year's corn stalks that have borne their crops and done their duty. The next thing to do is to remove all dead branches in the trees that are left, sawing them off clean next to the collar, and painting over the wounds. There will no doubt be quite a good many live branches that are crossing each other and making trouble, and right here you want to go slow. If there are very many, don't cut them all out in one year, and give the tree such a shock as a man would have if all his arms and legs were removed at one time. Better take three years to do this part of the job removing the most necessary third of them the first year. You can do it at any time after the leaves have fallen that suits your convenience, if you will take the trouble to paint over the wounds to keep them from drying, checking and rotting.

Selecting Varieties
In selecting varieties for a new orchard one should not choose too many of the early summer ones which must be used up as soon as ripe or go to waste. In the description of the different fruits we list will be found the length of time they may be expected to keep under favorable conditions. 


\section{Apples}

Apple Varieties
Of all the fruits grown in the Northwest, the apple and the demand for them is constantly increasing, both for home use and for shipping. No city garden should be without sufficient apple trees to produce fruit for home use and the farm garden can easily be made to bring a handsome return for the amount of labor necessary by planting a few apple trees of the right variety. The following list will be an aid in making a selection.

\section{SUMMER VARIETIES}

\section{DUCHESS, OLDENBURG} -A large beautiful apple streaked red on yellow, tender and juicy. Fine for cooking, very productive. Ripens early in September.

EARLY HARVEST-Medium to large, pale yellow, tender with mild fine flavor. Ripens from middle to last of August.

\section{LIVELAND RASPBERRY} - OA Russian origin, color white shading to crimson, flesh white, very juicy and sweet. Tree very hardy. Ripens in August.

\section{YELLOW TRANSPAR-} ENT-Medium size, wh it e

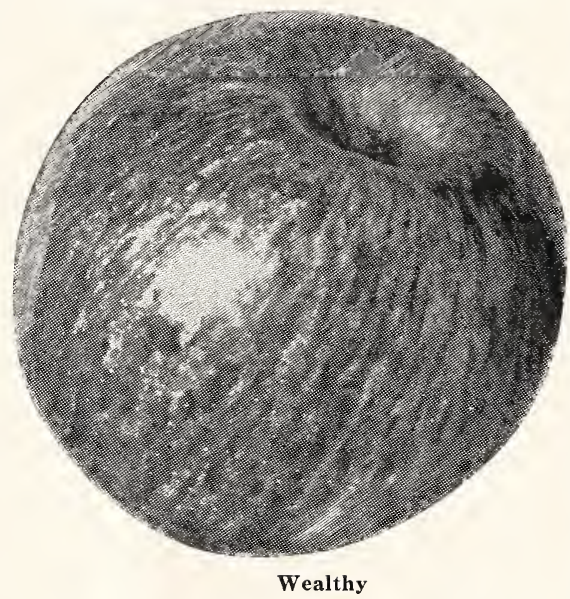
changing to lemon yellow, smooth waxen surface, of good quality with crisp flesh. Keeps well for an early apple. Ripens in August.

\section{FALL VARIETIES}

OKABENA-Extremely hardy and free from blight, prolific bearer. Fruit large, strongly resembling the Duchess but keeps much better. Season September and October.

HIBERNAL-One of the hardiest apples grown. Fruit large, handsomely striped, fine for cooking and for pies. Perfectly hardy up to the Canadian line. Best for top working to winter sorts. Season September to November.

PATTENS GREENING-Tree extremely hardy. Productive and an early bearer. Fruit large, green when picked changing to yellow. Fair for eating and excellent for cooking. Season September to December.

WOLF RIVER-An iron-clad that was originated near Wolf River, Wisconsin. Fruit is extremely large, greenish yellow, turning to crimson on top, tender and juicy. Season September to December. 


\section{WINTER VARIETIES}

ANISIM-Hardy and remarkably free from blight, fruit small, somewhat rough, but of rich red color, tender and juicy, fine for eating or cooking. Season September to January.

DELICIOUS-Originated in Iowa and is considered fairly hardy. Fruit is round, long, tapering, deep red running to yellow at the tip. Has a delightful flavor and has becn kept in cold storage until May. Valuable for home or commercial orchards.

LONGFIELD-A very hardy apple, early and abundant bearer. Fruit large, conical yellow, striped with red, sub-acid. Season September to January.

McMahon's WHITE_Large round, almost white with faint blush. Flesh white, tender, tart, not very firm. Tree vigorous and hardy, bears young and abundantly. Season October to February.

McINTOSH_Tree vigorous with spreading liead, a good annual bearer. Fruit above medium size, smooth, yellow covered with crimson, flesh snow white, crisp, very tender, aromatic and sub-acid. Season October to January.

MALINDA-An irregular but steady grower of about the same hardiness as the Wealthy. Fruit Medium, green, with blush of red. Flesh hard, good grained, sub-acid, good flavor. Season October to March.

\section{NORTHWEST G R E E NIN G-}

Tree of $\mathrm{Viscon-}$ sin origin, vigorons and hardy. Fruit large, nearly round, of greenish yellow color, flesh yellow, fine grained and firm, subacid, smooth and attractive. Season December to May.

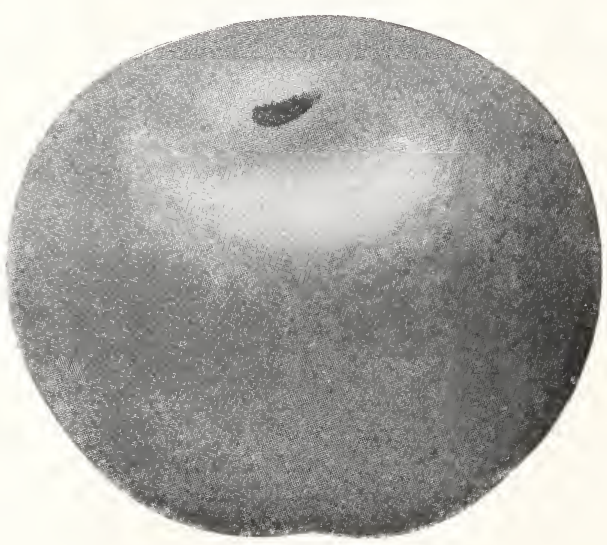

Anisim

Withrow, Minn., April 22, 1925.

Gentlemen: Stock arrived in fine condition and everybody pleased with the goods.

(Signed) BERNARD ZAHLER. 
PETER-A Minnesota seedling from the Wealthy which it resembles in size and color. Tree hardy and bears extremely early. Season October to January.

WEALTHY-Fruit large, red, regular and of the very best quality. Tree vigorous and thoroughly hardy and bears very young. A good market variety. Season October to February.

\section{The Famous Perkins Seedlings}

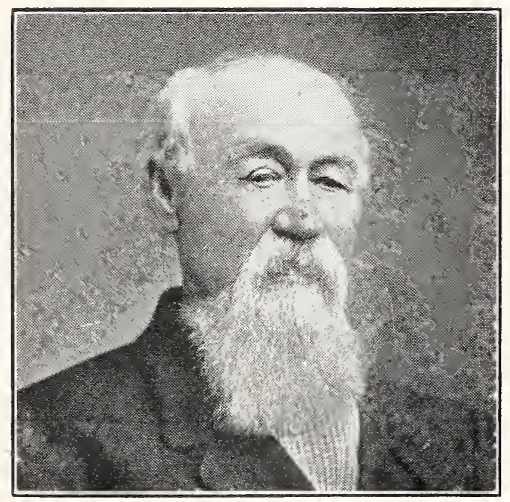

The Late T. E. Perkins

There is perhaps no one man who has contributed more hardy varieties of winter apples to the growers of the Northwest that the late Mr. T. E. Perkins of Red Wing, Minnesota. Back in the spring of I893 Mr. and Mrs. Perkins decided to plant some seeds from Malinda apples which they had grown in their own orchard and stored through the winter. The seedlings from this sowing were later transplanted into an orchard of about one hundred and fifty trees, being crossed with different hardy Northwest apples. As this orchard came into bearing it soon became famous throughout the Northwest, selections from it sweeping the boards at the state fairs and carrying of the highest premiums at the annual meetings of the Minnesota State Horticultural society. In I903, ten years after planting the seed, Mr. Perkins made an exhibit at the meeting of the American Pomological Society at Boston and carried off the Wilder Medal in competition with all of North America, and the same year at the Louisiana Purchase World's Fair at St. Louis, he won the gold medal in competition with all comers. 


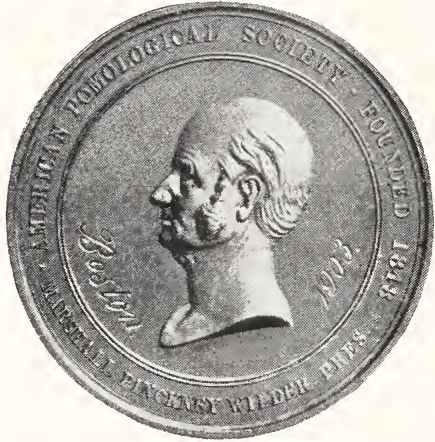

Wilder Medal won by Perkins Seedlings at American Pomoloogical Exhibition at Boston in 1903 in competition with all North America.

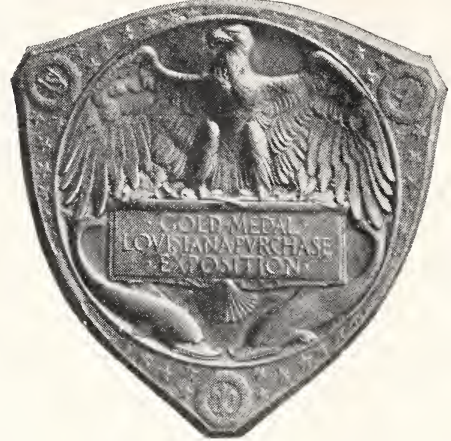

Gold Medal won by Perkins Seedlings at the Louisiana Purchase World's Fair at St. Louis in 1903 in competition with all comers.

GOODHUE (No. I2I) - A splendid mid-winter apple resembling the Wealthy, but larger and apparently a much more hardy and vigorous tree. Fruit rich red color, delicious flavor and hangs well on the tree until fully ripc. Not much subject to blight. Keeps until February.

JUMBO (No. 8I) - Largest apple of all the Perkins seedlings. Fruit about the size of the Wolf River but of far better quality. Fruit red over yellow, fine grain, mild-acid. Tree vigorous hardy and a prolific bearer. Keeps until January.

RED WING (No. 59)-One of the best of the original Perkins Seedlings. Has stood sixteen winters in Manitoba, where very few apples survive and has borne fruit each year. Fruit is conical in shape beautifully striped and splashed with red, hangs tight to the tree until ready to pick. Flesh firm, fine grained and very juicy, quite sour when picked but becomes fine for eating in mid-winter. Tree a spreading grower and not subject to blight. Keeps until May.

RHODA (No. 54) - A recent but wonderful addition to our "Perkins Family." Fruit has a distinctive appearance being peculiarly oblong in shape, medium size, striped to deep red in color. Flesh firm, fine grained and sweet. Tree hardy and does not appear to be subject to blight. Keeps until June.

PERKINS (No. 72)-We firmly believe that this apple far surpasses anything that has yet been produced as a winter variety for the Northwest. This apple has been kept under favorable conditions for one year and then exhibited at the Minnesota State Fair. The fruit, which resembles the Baldwin very much, is large, rich red, round as a ball and though very hard at picking time it becomes fine for eating during middle or late winter. It is almost impossible to shake the apples from the tree until thoroughly ripe. The tree is a rapid, robust grower, free from blight and has proven perfectly hardy wherever it has been planted. There should be a place in every orchard for this splendid apple. Keeps well into May or June. 
THE HARALSON-A late winter apple of wonderful color and exceptional quality. Tree unusually hardy. This apple is one of the Minnesota Fruit Breeding Station's most wonderful creations. Released about four years ago as No. 90, later named Haralson in honor of its propagator, Mr. Charles Haralson, then Superintendent of the Fruit Growing Station. Of deep, dark red color. In quality, by many considered fully equal, if not superior, to the Wealthy. The tree is exceptionally strong. Branches wonderfully shouldered, and there is no danger of breaking off, like many other varieties. In popularity, Haralson stands alone. So far, we have not been able to meet the demand, and for that reason we have not been able to supply larger, trees than one year old. Haralson is the only real winter apple for Minnesota. It is what the fruit growers of this state have been looking for and we predict that it is only a question of time when Haralson will be as well known among fruit growers and the public of the State of Minnesota, as the Wealthy. Under ordinary cellar conditions, will keep until early spring.

\section{Crab Apples}

DARTT'S HYBRID-Grown from Telofsky seed, supposed to be crossed with the Hyslop Crab. An erect rapid grower, comparatively free from blight and combines the quality of the apple with the hardiness of the crab. September to October.

EARLY STRAWBERRY - Tree very vigorous and productive, flesh juicy, rich, sub-acid, with an agreeable flavor. August.

EXCELSIOR-One of our very best varieties for farm and garden purposes. Fruit of medium size and fine for sauce and pickles. Tree hardy, not subject to blight and an early and consistent bearer.

FLORENCE-One of the hardiest of all and an early and profuse bearer. Fruit larger and considered by some superior to the Transcendant. August to September.

HYSLOP_This variety has been long and extensively cultivated. Trees are hardy and strong, fruit large, deep red when ripe, produced in clusters. Fine for cooking and for cider. September and October.

MARTHA-A new crab raised from the seed of the Duchess. Fruit large, beautiful and showy. Bears early and profusely. Makes fine jellies and sauce. September.

MINNESOTA-A medium grower, hardy, best of the winter varieties for size and keeping qualities. The fruit is large and yellow, splashed with red on sunny side, fine grained, juicy, and of an excellent flavor.

ORANGE-This standard variety has been long tested in the north and has been found to be in a class by itself for hardiness and good shipping qualities. The fruit is large, even, deep orange when ripe; flesh white, fine grained, crisp, and juicy; flavor delicate and sweet; makes a fine amber jelly and is a splendid canner.

RED SIBERIAN-One of the most popular crabs, large and beautifully colored. Fit for preserving in September and October.

SOULARD - A cross between the wild crab and the common apple. Fruit makes excellent preserves and fine for jellies and jams. Tree bears early and makes rapid growth. Ripens late and keeps well. 
SWEET RUSSET-Large, round, conical, green russet, with faint blush. Very rich, sweet, one of the best for eating and cooking. Auguse and September.

TRANSCENDANT-An old favorite and a beautiful variety of the Siberian Crab. Red and yellow. Quite subject to blight. Not recommended on that account. August.

VIRGINIA-A fine grower, free from blight. Fruit size of Transcendant, color red. Fine for cooking and for cider. September and October.

WHITNEY-Very hardy, productive, handsome foliage. A dessert apple of good quality. Color red, flesh juicy, tender and rich. Comes into bearing very early. September.

YELLOW SIBERIAN-Fruit medium size. Clear pale yellow. An excellent crab for preserves and pickles. Tree very hardy, healthy, comes into bearing very young. September and October.

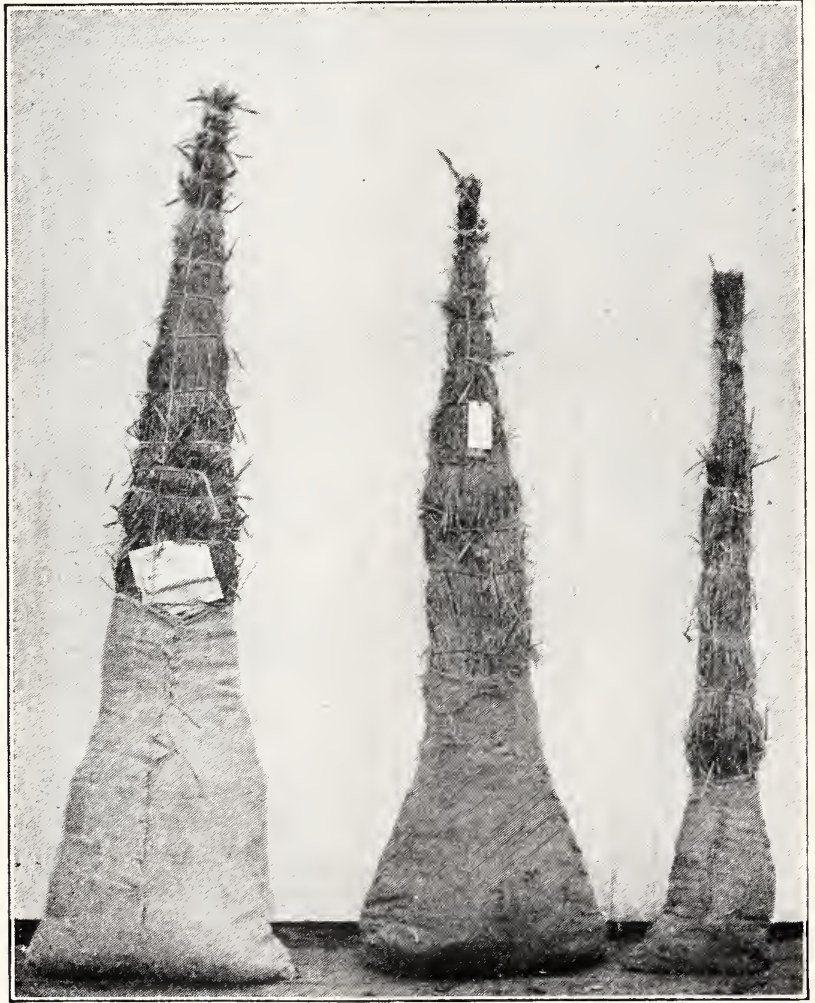

Service

That

Pleases 


\section{Plums}

The plinm is the natural tree fruit of the North. No farm or village home even in North Dakota and Montana need be without this luscious fruit which is as easily raised in this climate as oranges in Florida or peaches in New Jersey. They begin bearing early, often the next year after planting and continue so abundantly that they bear themselves out in ten to fifteen years. The native plums of this section were small and not always of the best flavor but during the last twenty-five years horticulturists have by experimenting and cross fertilization with Japanese and European plums brough forth new and improved varieties that are equal in size and superior in flavor to the choicest California plums usually found in fruit stores.

When planted alone, or not used as filler in the orchard, plums should be planted about sixteen feet apart. Several varieties should be planted together in order to allow the blossoms to cross pollenate. Trim back to form a head about three feet from the ground and each year cut back the rank growth of the branches before they reach the size of a lead pencil. Suckers that shoot up from the roots should be kept cut away and the ground kept well mulched and cultivated. Spraying should not be neglected and should be thoroughly and effectively done at least twice each year. Should they set fruit too heavy to ripen easily shake off the excess when it is about the size of a wild cherry. This will prevent overtaxing the vitality of the tree and insure a uniform crop each year.

DE SOTA-Fruit medium size, yellow with red cheek, fine for eating and canning. Flesh yellow and rich. Moderate growth, bears young and profusely. Hardy and very desirable.

ELLIOTT-Tree vigorous, very hardy, upright spreading growth; fruit medium to large, round-oval, red; flesh firm, juicy; quality good; stone small, cling; season late, about September first. Promising as a market variety because of its productiveness and regular bearing.

FOREST GARDEN-Medium size early variety of good quality. Nearly round, mottled red and yellow, sweet and rich. A strong and vigorous grower and perfectly hardy.

NEWPORT -A plum tree of striking appearance; moderately vigorous, upright growing, hardy, foliage of a deep reddish-purple color, retaining its color throughout the season; fruit is small to medium in size, of very poor quality and of little value. The tree is valuable for its striking foliage color.

WYANT-Large, round, oblong, purplish red, thick skin which peels easily; flesh firm, a perfect freestone and of excellent quality. A native of Iowa and very hardy. 
HANSKA-A cross between the native plum and the fine fragrant Apricot Plum of China. Tree a strong upright grower and early and full bearer. Fruit large, firm, bright red; flesh yellow and of a delicious apricot flavor. Excellent for eating raw or for cooking.

KAGA-A cross between the wild plum and the famous Chinese Apricot plum. The fruit is large, somewhat oblong, dark red in color; flesh firm, fine eating out of the hand and fine for cooking or canning as it retains the apricot flavor.

KAHINTA-Cross between the Japancse Apple Plum and the Terry. Fruit $\mathrm{I} 1 / 2$ inches in diameter, dark red, roundish, slightly oval, freestone, skin thin, flesh firm, yellow and sweet, and of excellent quality. Pit very sniall. Bears young and very heavy.

LORING PRIZE-This variety was originated near Faribault, Minnesota, and succeeded in carrying off the prize offered by the State Horticultural Society for the best Minnesota plum. Tree is thrifty and perfectly hardy. Fruit very large, from $13 / 4$ to $2 \frac{1}{4}$ inches in diameter, nearly free stone, bright red, flesh yellow and of a delicious flavor superior to the California plum. Fine for market purposes. Tree bears when three to four years old.

MONITOR-Tree medium in size but vigorous, produces a compact, rounded, well-shaped head, hardy and productive; fruit is large, roundish, well colored, with dark, dull red; flesh firm, moderately juicy, sweet; quality good; stone medium in size, cling; late mid-season. Very promising as a market plum.

OPATA-A cross between the Sand Cherry and the Japanese Gold plum. Tree very hardy, spreading grower and heavy bearer. Fruit a little larger than the wild plum, deep purplish red splashed with green; flesh deep green, firm, and of excellent quality, small pit.

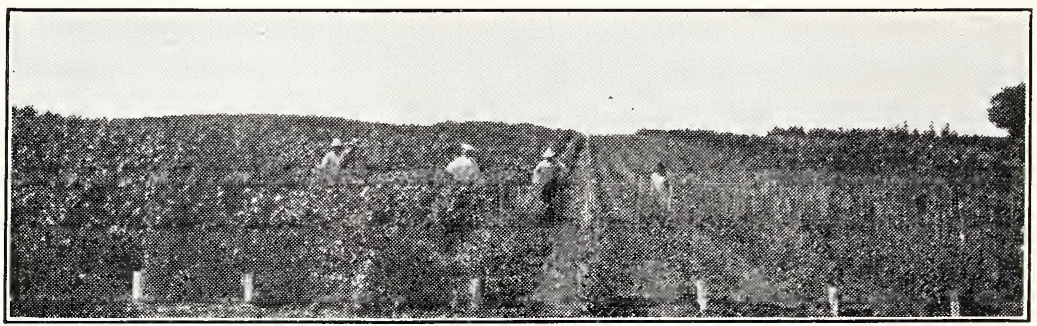

One Corner of an Eighty Acre Fie'd of Plum Trees

Loretto, Minn., March 31st, 1925.

Gentlemen: Out of a total order of forty trees, I want to say that I did not lose a tree last year. Good stock and careful planting. Please send me some information about the planting and care of Walnut trees. In planting for the parish and summer resort crowd, I want to make a success and show the best.

(Signed) REV. A. ZISKOVSKY. 
RED WING-Tree is moderately vigorous, upright spreading, quite hardy; fruit very large, firm, yellow overlaid with bright red; flesh moderately juicy, sweet; quality very good; stone medium to large in size, entirely free; mid-season. An excellent variety. for home use and an attractive market plum.

SAPA-A cross between the Sand Cherry and the Japanese Sultan plum. Tree somewhat dwarf, rapid grower. Fruit small dark purplish red splashed with green; flesh and juice of a rich dark purple and of a rich flavor, small pit; excellent for canning and for sauce and pies.

SURPRISE-A fine native variety considered by many as one of the best of the cultivated varieties. Tree large, healthy grower and of the hardiest type. Fruit large, medium thick tender skin, bright red; flesh pale yellow, mealy, of fine flavor and good quality.

TERRY-This plum has also been known as "Free Silver." Fruit round, red, of medium size; flesh yellow, firm and of fine flavor. Perfectly hardy in all sections of the Northwest.

TONKA-Tree of medium size and vigor, of upright spreading growth, hardy; fruit roundish, large, dark red; flesh firm, juicy, sweet; quality good; stone very small, free or nearly free at maturity; early

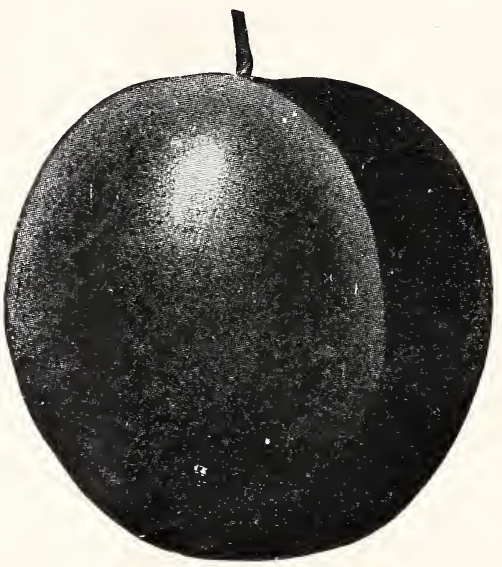

Surprise mid-season. Especially recommended for home and market because of its extremely high productivity, its good quality and ability to stand up well in storage or transit.

UNDERWOOD-Tree extremely vigorous, large size, of spreading growth, forming a round head, very hardy and very productive; fruit is large, roundish-oval, attractive red in color; flesh juicy, fairly firm, hangs well to the tree, ripens very early and continues over a long season; stone is small, cling; quality excellent.

Eleva, Wis., May 19, 1923.

Gentlemen: I have handled quite a few shipments of nursery stock but nothing to compare with such careful packing and satisfactory way of shipping nursery stock. I have taken all the patience to unpack and plant those 100 Evergreens, that I know of, to make them grow, and even being four days on the road before I received them is no reason why they should not grow, so I can surely recommend you to all I have a chance to meet, that you give better satisfaction than any nursery I know.

Respectfully,

(Signed) CARL SAKRISON. 
WANETA-A cross between the Terry and the Apple Plum, a large Japanese variety. The fruit is large, often reaching two inches in diameter. Fruit of a deep red, yellow flesh and a delicious flavor. Tree is perfectly hardy and a rapid grower.

WINONA-Tree very vigorous, spreading to slightly drooping, very hardy and regular bearer; fruit large, yellow with red flesh, roundish; flesh firm, crackling, juicy, sweet; quality of the highest; stone medium in size, semi-cling. The variety is somewhat more subject to brown rot than other of the hybrids.

WOLF-Fruit large, dark red, good quality. Excellent for cooking and canning, is a vigorous grower, perfectly hardy, and an abundant bearer.

\section{Cherries}

Cherries are being grown more and more throughout the Northwest. While the eastern varieties have not proven very successful in this section, particularly the sweet cherries, there has in the last few years, been considerable advancement in the production of hardy kinds. By cross breeding, horticulturists have brought out some new varieties that are particularly adapted to this section and with fruit of a quality that compares very favorably with the older sorts. Cherries should be given the same care as plums and it is best to keep them trimmed to bush form as much as possible. The varieties we list are hardy and productive anywhere in the Northwest.

ZUMBRA CHERRY-A low growing tree, vigorous and very productive, showing the characteristic profuse bearing habits of the sand cherry crosses. The fruit reaches one inch in diameter and is borne in thick, rope-like clusters along the slender branches of last year's wood. Color very dark, nearly black when ripe; flesh firm, greenish, sometimes tinged with red when fully matured; stone small, free; quality good with a flavor resembling its sweet cherry parent. This cherry is destined to surpass all other productions for cherry growing in Minnesota, the Dakotas and Wisconsin. One of the most promising of the fruit breeding farm productions.

COMPASS CHERRY-Originated in Minnesota. A cross between the Rocky Mountain Cherry and the Native Plum, and resembles both. The most remarkable fruit of recent origination. Hardy as any wild plum. Sweet, juicy and excellent flavor. Marvelously prolific bearer. Grows on any soil. Fruits every year-never misses. Bears second year after planting. Good shipper and a fine cooker. This cherry is perfectly hardy in Minnesota, Wisconsin, Iowa, the Dakotas and Montana.

\section{The Home Orchard is one big step toward solving the problem of the high cost of living.}




\section{Grapes}

It is only recently that grapes have received any particular attention in the Northwest and it is very doubtful if any fruit has made more rapid strides in this section than the grape. Many can remember when the cultivated grape was almost unknown here, likely because of the fact that Eastern grapes could be bought upon the market in their season for from ten to twenty cents a basket, while today the basts alone cost nearly that amount. Today this is all changed. The Eastern and Western grape has advanced in price until it has almost become a luxury and in its place has been brought fruit of native origin that is equal in every respect to those of former years. They should be planted in good rish soil in a sunny location and cut back to six inches from the ground at planting time. It must be remembered that grapes bear on new wood only and should be cut back severely after the leaves fall each year. A three wire fence is perhaps the most satisfactory trellis on which to train them, but the posts should not be more than a

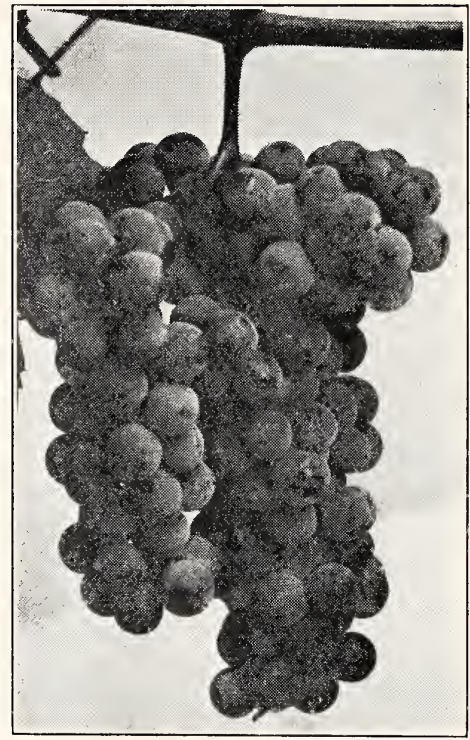

Beta rod apart in order to furnish sufficient support for the heavy new growth each year. Set plants eight feet apart in the row and rows eight feet apart. Many of the varieties we are listing are the product of the Minnesota Fruit Breeding Farm, where they have been given the most rigid tests.

AGAWAM-A light red berry of good size. One of the strongest growers with fruit of an excellent quality. Not extremely hardy but survives well with winter covering.

ALPHA-A recent production somewhat like the Beta but considered by some to be superior. Fruit a trifle smaller than the Concord and sub-acid. Perfectly hardy in all sections.

BETA-A northern seedling crossed with the wild grape which has proven entirely hardy in North Dakota without winter covering. Fruit of medium size and of a flavor midway between the Concord and the native wild grape. Ripens early and is seldom effected by late spring frosts. 
CONCORD-An old standard variety and the most popular grape in America. Fruit large, round, sweet and borne in huge clusters. Vines hardy and vigorous.

DELAWARE-Still holds its own as one of the finest grapes. Fruit light red, medium size, round, thin skin, flesh juicy, exceedingly sweet, spicy and delicious flavor. Should be covered in winter.

HUNGARIAN-A white grape that is very productive with small compact bunches. Fine, sweet flavor. Not quite as hardy as the Beta but does not need winter protection.

MOORE'S DIAMOND-One of the best white grapes. Fruit juicy and sweet and ripens early. Vines vigorous and hardy but should be covered in winter.

MOORE'S EARLY_Ranks next to the Concord for both home planting and commercial vineyards. Less vigorous and fruitful than the Concord but earlier and somewhat better quality.

NIAGARA-The hardiest white grape. Bunches large, berries medium to large. Skin thin but tough and does not crack. Of good quality and has a flavor peculiar to itself.

SUELTER-A new Minnesota production, somewhat resembling the Alpha and Beta in size and color. Has proven a wonderful addition to the Northwest varieties. Has a fine flavor and good shipping and keeping qualities. Bears early and very heavy when given proper pruning and care.

WORDEN-A seedling of the Concord, larger, sweeter than its parent but not so vigorous and prolific. Ripens about ten days ahead of the Concord. Vine as hardy as the old standby and in every way as healthy.

\section{Gooseberries}

There is probably no small fruit grown in the gardens of the Northwest that produces so abundantly every year with so little care as the Gooseberry. They do well on any soil that is suited to wheat or potaties and there is always a good market for the fruit. Cut back same as currants and set from three to four feet apart in the rows and the rows four feet apart to allow for cultivation. Spray thoroughly as soon as the leaves are out and again when the fruit is set (see spray pro-

Willow City, N. D., Aug. 26, 1924.

Dear Sir: Just a few lines to tell you that 1 am very much pleased with the Beta Grapes that I got from you. Every plant grew and looks hardy. Now, if they will only winter, they will be the grape for this country. I am trying hard to get people to try them so if you hear from some one around here that want to try some, will you kindly refer them to me and I can show them mine. Will you also send me your latest price list?

(Signed) MRS. A. R. LIZOTTE. 
gram). Gooseberries, like currants, bear on both old and new wood, but all wood three years old should be kept trimmed out as the fruit of the younger wood is larger. Keep cultivated and mulched during the summer.

CARRIE_Of Minnesota origin. Fruit pale red, of good size and excellent quality. Bushes quite free from thorns, very thrifty, and not much subject to rust or mildew.

DOWNING-This is perhaps the nost popular gooseberry on the market, though not quite as hardy as some. Fruit light green, sweet and fine, large in size.

HOUGHTON-Pale red when fully ripe. Thin skin of the best quality for canning and pies. Bears abundantly and is perfectly hardy anywhere.

PEARL-Fruit is very large, of a good quality for canning when green. Not so valuable when ripe. Resembles the Downing, only larger.

RED JACKET-Larger than the Houghton, its parent. Vigorous, productive, red when fully ripe. Fine for preserves and for table use. Entirely hardy.

CHAMPION-An Oregon seedling. Fruit large and of good quality. Very productive. Hardy and well adapted to this section.

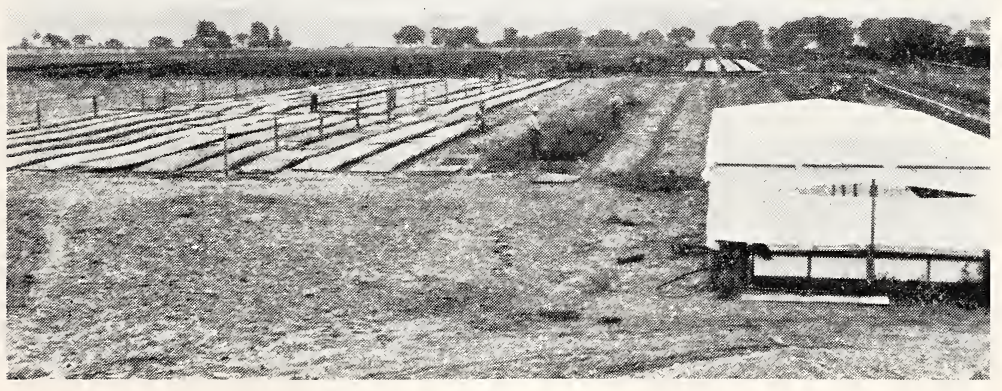

A View of Our Propagating Beds, 


\section{Currants}

No farm or city garden should be without currants. They can be planted along the edge of the garden or between apple and plum trees. They are fine for sauce and pies and make excellent jelly. They need only ordinary care. When planting cut back severely and set them three to four feet apart in the row and the rows four feet apart. Mulch with straw or litter and spray each year as soon as the leaves are out and again when fruit is set. Currants bear on both old and new wood but the younger wood bears larger iruit. After the fruit is picked, cut out all wood that is three years old. This will allow for a greater growth of new wood for the rollowing year.

PERFECTION-An unusually large red berry borne in good sized bunches. Fine for table use and for marketing.

CHERRY-A large red berry in medium sized bunches. Modest grower and does better where it has partial shade.

FAY'S PROLIFIC-One of the best known and universally used by large fruit growers. Plants are hardy and productive and fruit is of fine flavor.

WHITE GRAPE-Large white berry on long bunch. One of the best white currants.

POMONA-A choice red currant for both market and home use. Large berries full bunches of good size, sweet and fine quality.

LONDON MARKET-Bush vigorous, upright, fruit medium to large, color dark red, sprightly acid flavor, very productive.

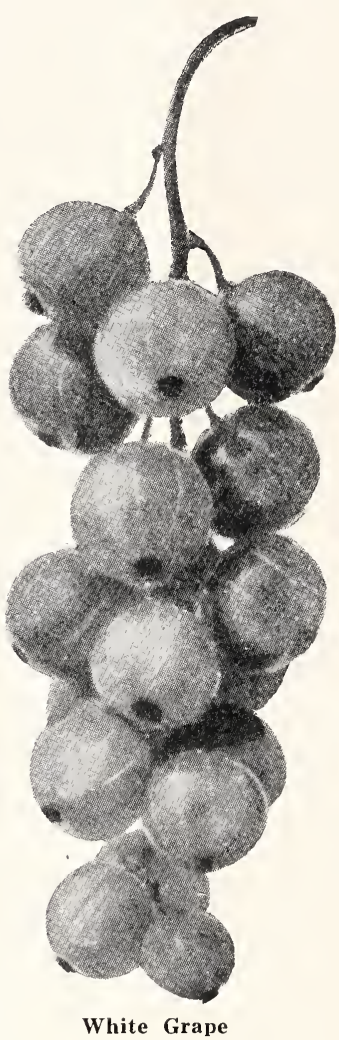

WILDER-One of the best varieties grown. Superior in every way to the common sorts. Branches and berries large, color red, splendid quality.

VICTORIA--Bush very strong, upright grower, clusters of fruit, medium length, bright, medium size berries, very productive.

RED DUTCH-An old reliable variety. Fruit brilliant red, large berries borne in long clusters and the quality is excellent.

NORTH STAR-Both berry and bunch are very large. Fruit very sweet, rich and firm. Good market currant.

WHITE TRANSPARENT-One of the very best white currants. Fruit large, sweet and firm, borne on heavy long clusters. Bushes are prolific and remarkably free from disease. Make excellent pies and sauce. 


\section{Raspberries}

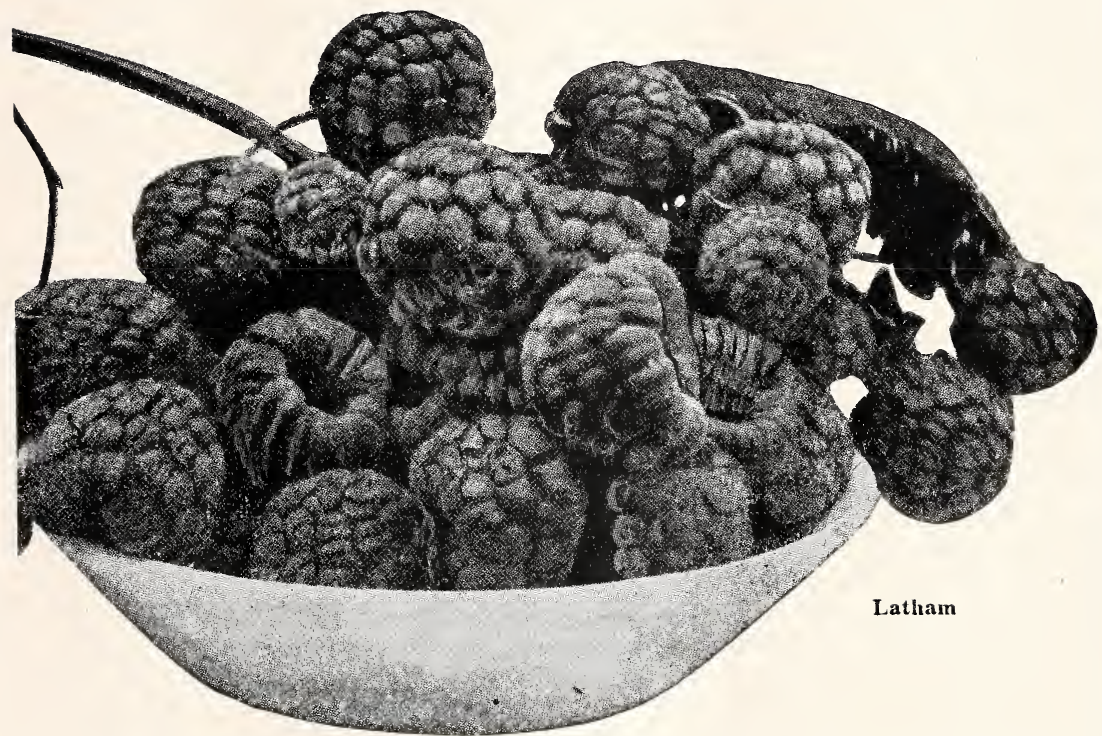

The Raspberry is one of the best small fruits for the Northwest and can be grown almost anywhere without any great amount of care. It is one of the most palatable of all fruits with practially no waste or extra work in canning, and produces good crops every year. There is always a good demand for Raspberries and the prices are always high. Plant either in rows six feet apart and three feet apart in the row or in hills four to five feet apart. Care should be taken not to plant too deep; cover the bud and roots with about one inch of dirt. Cut the canes down to about six inches at planting time and as the new shoots come up pinch the tops back when about two feet high to make them stalky. Raspberries bear on new wood and after picking time all old canes should be cut out. Cultivate only enough to keep the weeds down and only shallow as the roots grow near the surface and are easily injured. Mulching always pays. Spray just before buds open with lime sulpher or Bordeax Mixture. All red raspberries sprout from the root.

\section{RED RASPBERRIES}

CUTBERT-Fruit large, bright red. Hardy but needs winter protection. Fine for market and home use.

KING-A good standard variety that has given universal satisfaction. Berry is large, firm, bright red and a good market sort.

LOUDEN-Large and beautiful dark crimson fruits of very good flavor. Hangs well on the bushes after ripening and firm for shipping. 
MARLBORO-One of the largest early red berries. Bright scarlet, sub-acid, pleasant flavor and very productive. Fine for shipping.

MILLER-A comparatively new variety and very early. Medium size fruit and very productive. Very firm and can be shipped a long distance safely.

LATHAIM (MINN. No. 4)---This new red Raspberry is the product of the Minnesota Fruit Breeding Farm and seems to combine in one all the good qualities of the older varieties. It is hardy, healthy and productive, with the best best of flavor and an exceptional size.

ST. REGIS (Everbearing)-A bright red Raspberry producing a scattered crop of fruit continuous from June to September. Fruit is formed on current scason's wood and is of excellent quality. Bears same year as planted.

TURNER-A beautiful berry of fine size and exccllent quality. Fruit firm and reliable in every way.

OHTA-An everbearing variety that bears well the first year. Of good quality and fruits during a long period.

REDPATH-The largest and most attractive red raspberry yet introduced. A firm, dark red berry, of the Latham type, often an inch in diameter. Ripens a few days later than King and extends over a period of six weeks. A good, reliable shipping berry, of highest quality for general use and demands the topmost price in the market. After several years of trial alongside the older varieties of raspberries, Redpath has proved to be the hardist bush and the most vigorous growing cane of all raspberries. This, with the fact that it is the most productive of any variety makes it a berry to be depended upon, and a real money-maker for the grower.

COLUMBIAN-Plant a giant in growth, very hardy. Fruit large, dark red, rich juicy and delicious flavor, does not drop from bush. Does not sprout from roots.

SUNBEAM-This has proven perfectly without winter protection. Fruit large and of good quality. Fine for canning.

\section{BLACK RASPBERRIES}

CUMBERLAND-Berries large and even in size, bears abundantly and ripens mid-season. Strong grower and one of the hardiest.

GREGG-Of good size, fine quality, productive and hardy, firm, sweet and rich. Strong grower and good bearer. Ripens late and evenly and is a good market berry.

NEMAHA-A Nebraska seedling of the Gregg and is almost identical. Fruit a little later, of better quality and hardier than the parent.

OLDER-One of the lately introduced varieties which has been receiving considerable attention in the Northwest. Ripens a trifle carlier than the Gregg. Hardy and reliable. Does not sprout from roots.

\section{BLACKBERRIES}

Blackberries are a wonderful fruit and help to fill the gap between raspberries and grapes. They are easy to grow, requiring about the same culture and care as Raspberries and succeed on most any well drained soil. All Blackberries sprout from the roots. Fruit is large, 


\section{The Best Raspberry Grown}

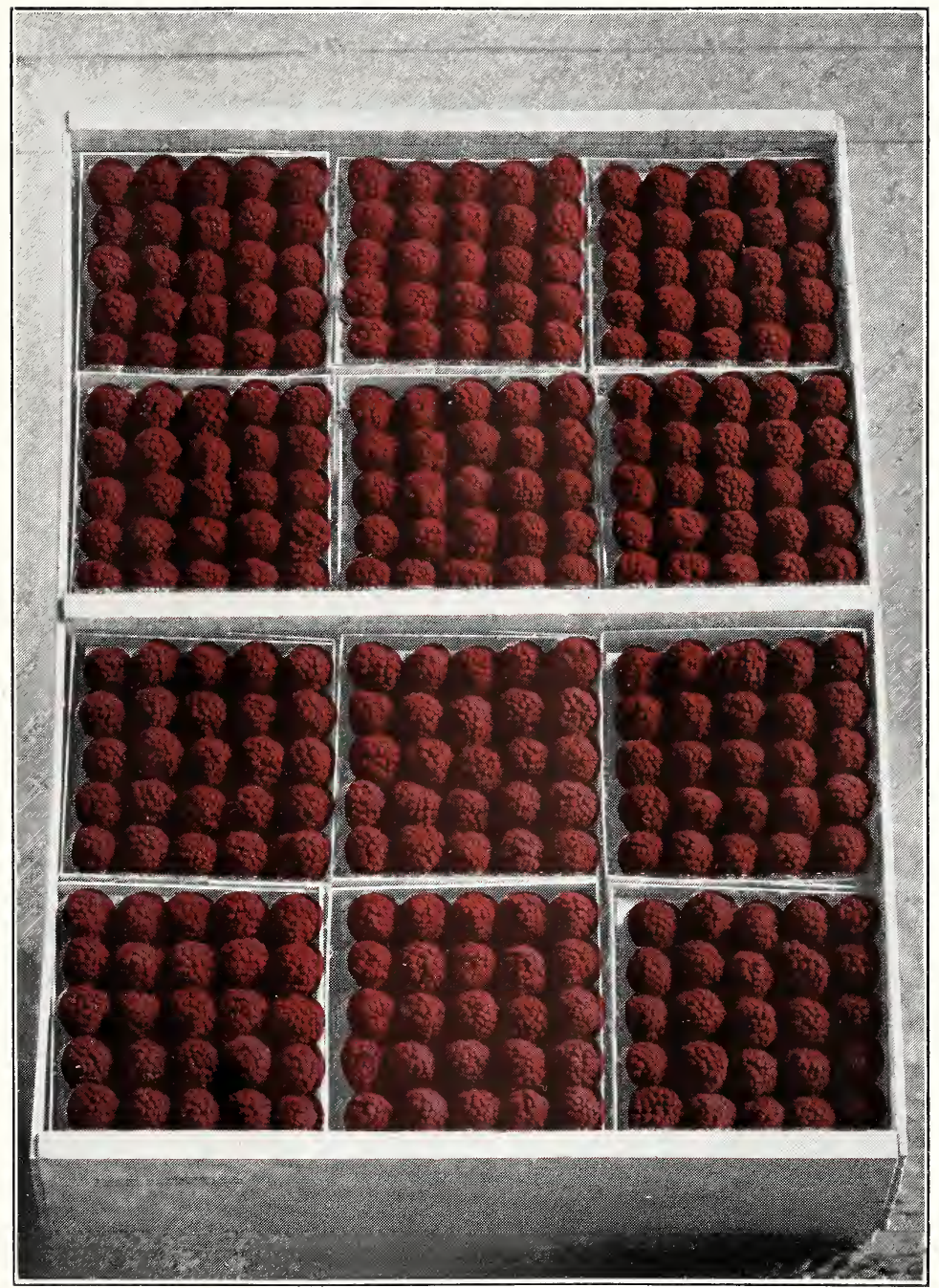

Redpath Strain Latham 

firm and fine for canning and pies. Blackberries should be covered in winter. Remove a spadefut of earth from the side of the plant, bend at the root and cover the entire plant with about two inches of dirt.

ANCIENT BRITTON-A remarkable market variety of medium size and best quality. Very hardy and berries sweet.

SNIDER-Medium size without hard, sour core. Not as thorny as other varieties. Extremely hardy and very productive. Ripens in good season.

STONE'S HARDY-A vigorous grower. Berry glossy black and of good flavor. A little later than the Snyder.

LUCRETIA DEWBERRY-A specie of the Blackberry that has proven successful. Fruit large, very showy, often measuring from one to one and a half inches in length. Very easy to cover on account of its trailing habit.

\section{Strawberries}

Everybody likes strawberries and there is no reason why anyone with even a small city lot cannot have an abundant supply for the table throughout the summer season. There is no fruit that produces so well for the small amount of ground required and the little care necessary. As a commercial enterprise they are also very profitable as there is never enough strawberries on the market to supply the demand and the price is always good. An acre of strawberries can easily be made to produce a net profit of five hundred dollars after it comes into full bearing. Strawberries succeed well in any soil that is adapted to ordinary farm or garden crops. Soil should be thoroughly prepared, well drained and enriched. For field culture set the rows three and one-half to four feet apart and fifteen to eighteen inches apart in the row. For garden the rows may be set closer. To produce fine berries do not allow the rows to become too heavliy matted. Pinch off the runners as soon as they get out about a foot from the row, leaving plenty of room for cultivation and mulch. After the ground is frozen in the fall cover the plants with a light coat of clean straw and this mulch should be raked off and left between the rows early in the spring. Care should be taken not to plant strawberries too deep nor too shallow, but so that the bud at the base of the leaves will be even with the surface of the soil. June bearing varieties should not be allowed to fruit the first year but with the Everbearing varities if the blossoms are kept pinched off until the first of August they may be allowed to bear a crop in the fall. Some varieties have imperfect blossoms and will not bear unless at least every third row is planted with a perfect variety so that they will pollenate. The varieties we list are all perfect and may be planted alone with success.

\section{JUNE BEARING VARIETIES}

AROMA--Plant shows no weakness of any kind. Fruit very large, rounded conical, rarely misshapen, glossy red, of excellent quality and produces in abundance.

BEDERWOOD-This variety is very desirable for early home use 
or near market. It is in every way healthy and vigorous. Berry is large size, roundish, bright scarlet and of good quality.

DR. BURRILL-A new variety that seems to be very popular wherever planted. Fruit similar to the Dunlap in size and appearance. An early and abundant bearer.

PREMIER-One of the most productive and best well tested early varieties. Fruit highly colored, firm, a splendid shipper, of superb quality. Strong, clean foliage, plant grows and spreads over its loads of fruit, protecting it from sunscald and rot.

SENATOR DUNLAP-An old standard variety that has been the leader for many years. Rampant runner, should be restricted in production of plants. Fruit good size, regular form, beautiful bright red, glossy, firm, splendid keeper and shipper, excellent quality. One of the best for canning.

\section{FALL OR EVERBEARING VARIETIES.}

CHAMPION-A wonderful new variety claimed by many to be superior to the Progressive. In Michigan, where they were originated, they have been planted extensively with entire success. A heavy producer and good plant maker. Fruit is of excellent quality.

DULUTH-Entirely hardy in central and northern Minnesota and in Canada, a fair plant maker and produces heavily both spring and fall when grown in the hill system. Foliage heavy, leaves medium size, dark green, covering and partially protecting the blossoms. Flowers perfect and medium in size, conical, dark red, with seeds slightly raised and red when fully ripe; flesh red, moderately juicy, fairly firm, slightly subacid; aromatic; of good quality. Spring crop late.

PROGRESSIVE-The standard by which all everbearing sorts are measured. Healthy, vigorous and productive. Stands hot and dry weather better than most sorts. Fruit deep red, medium size. Very high quality.

SUPERB-Plants are strong and stand the winter well after producing a heavy crop of fruit. Fruit is very large, round, rich, dark red, glossy, attractive and smooth.

\section{Miscellaneous}

ASPARAGUS_Can be planted either in spring or fall. Dig a narrow trench at least ten inches deep and fill the bottom with three inches of well rotted manure. Cover this with two inches of black soil in which plant the Aspargus. Cover with two more inches of dirt and leave balance of trench open until the plants grow out. Set plants one foot apart and rows two to three feet apart. Give a good top dressing of manure in fall, working it in between the rows in spring. Liberal applications of salt are also beneficial. We grow Washington Rust Proof, which we consider the best.

HORSE RADISH-Too well known to need description. Grows anywhere. We offer strong roots which should be planted in the spring.

RHUBARB-Easiest culture. Just what we need in spring for pies and sauce to thin our blood. A great medicine. We grow two kinds, 
Victoria, with tall, coarse, pink colored stems, and Linneaus, called wine plant, with smaller stalks, more tender and very fine quality. Both entirely hardy.

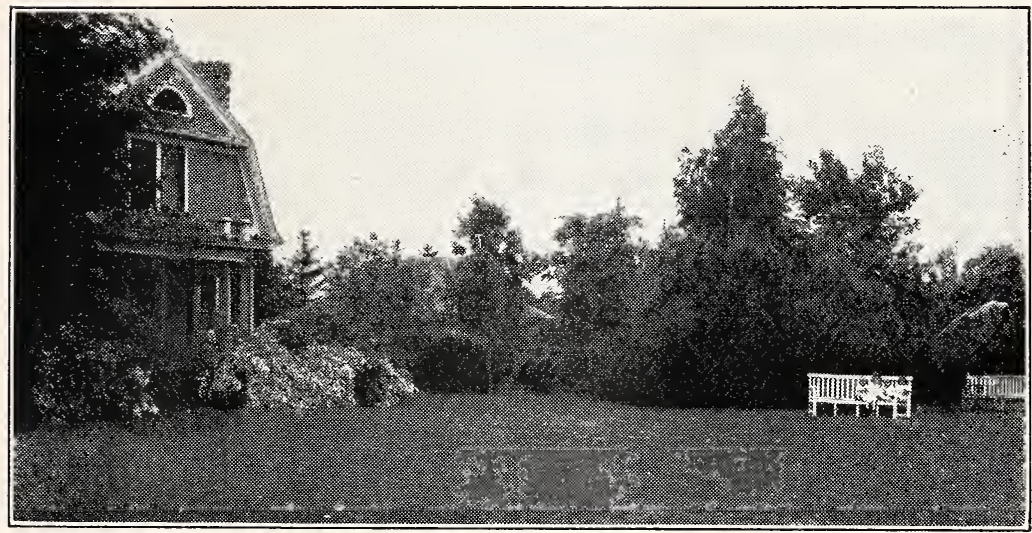

Effective Group and Foundation Planting

\section{Landscape Gardening}

In planting around your home grounds it is always best, where possible, to secure the services of an experienced landscape architect to view the premises and draw a definite plan for the entire grounds. He will not only be able to save you money but is equipped with a knowledge of colors and arrangements that will make the finished design a thing of beauty and everlasting service. It is not necessary to do all the planting at one time but the plan should be your first consideration and should be adhered to throughout. We maintain a landscape service department which will gladly aid you in every way and will draw plans if you will furnish us with a complete drawing of your grounds, showing location of buildings, walks, driveways and trees and shrubbery already planted. This service is entirely free where we furnish the stock for the planting and our customers are invited to avail themselves of it at any time. In case you wish to make a plan to suit your own ideas the following suggestions will prove of value, but above all, make your plan first. 
Houses and other buildings are not natural to the: earth's surface and do not appear happy and at ease unless they have what the landscape architect calls a "setting." No matter how fine the material or how beautiful the lines of the house may be, it is not pleasing to look upon unless it appears as part of the landscape.

The buildings and grounds should be a picture, the house, of course, should be the central figure but the surroundings should all lead up to it and harmonize with it. A house properly "set" looks homelike and comfortable.

Trees not only furnish a background for the shrubs and flowers, but they make a boundary for the sky. It is desirable to have a large sky space and this space should be as informal in shape as the clouds themselves. Trees should be chosen with regard to the size of the garden. For a small garden only shrubs should be used as a boundary or perhaps one tree or group of trees on the north side. For a large garden, trees may sometimes be used on all sides, as there will be plenty of space for sunshine anyway. The outline may be varied by using groups of various kinds of trees, so that it may be irregular and produce a most pleasing effect. It is well if the trees can be planted a year or two in advance of the shrubs and perennials. The border of woody growth, varying from low shrubs to high trees, furnishes a frame or setting for flowers, shielding the shade-loving ferns and other shade-loving flowers from the sun in one place, giving the flowers the advantage of his rays in another, and protecting the whole from the sweep of the wind. Remember, the desired effects cannot be realized in one or two years.

A look at Nature will reveal the fact that there is always a greater or less amount of shrubbery to be found in any grove where Nature has not been restricted. It is generally conceded that a lawn or park is not quite complete without a certain amount of shrubbery and perennials being planted. By careful study of the surroundings of a place, certain features may be more effectively brought into prominence, unsightly objects screened and a greater amount of comfort and coziness secured by a judicious arrangement and planting of shrubs and perennials.

There can be no general plan laid down for all places, each place being a law unto itself.

The first thing to be done is to study well the plot of ground under consideration; its slope, the relation it has to the surroundings, the kind of soil, the temperature and the buildings upon it.

Next study well the kind of plants desired, and, of these, select those that are best adapted to the conditions where they are to grow.

Avoid isolated specimens. A better effect will be obtained by grouping them and planting the tall varieties in the background, using the lower and dwarf varieties in the front. Do not plant shrubs in straight lines. It is well in outlining the border to have deep bays which will give a greater distance and also carry with them the idea of a mysterious passage to something beyond.

Shrubs may be used as a screen to hide unsightly objects. A barrier of living green makes any unpleasant object practically non-existant whether the space be large or small. If privacy is desired the shrubbery border may be so arranged as to almost completely exclude the outside world and yet allow views which will add a great charm to the grounds.

One of the most important points to be kept in mind is to harmon- 


\section{A Perennial Tranformation}

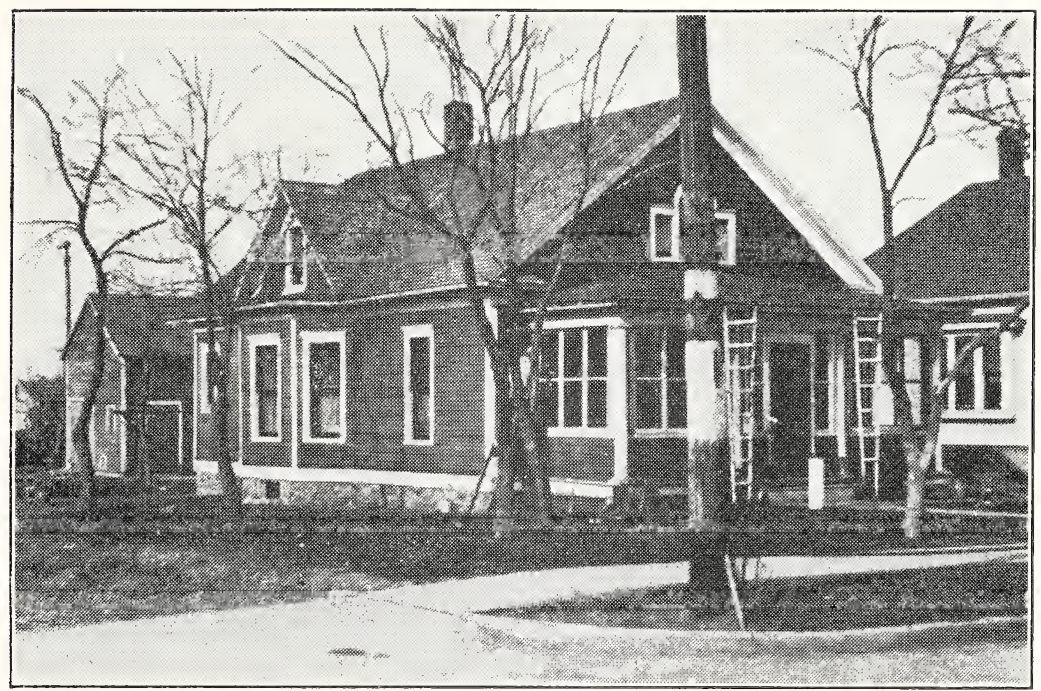

Before Planting

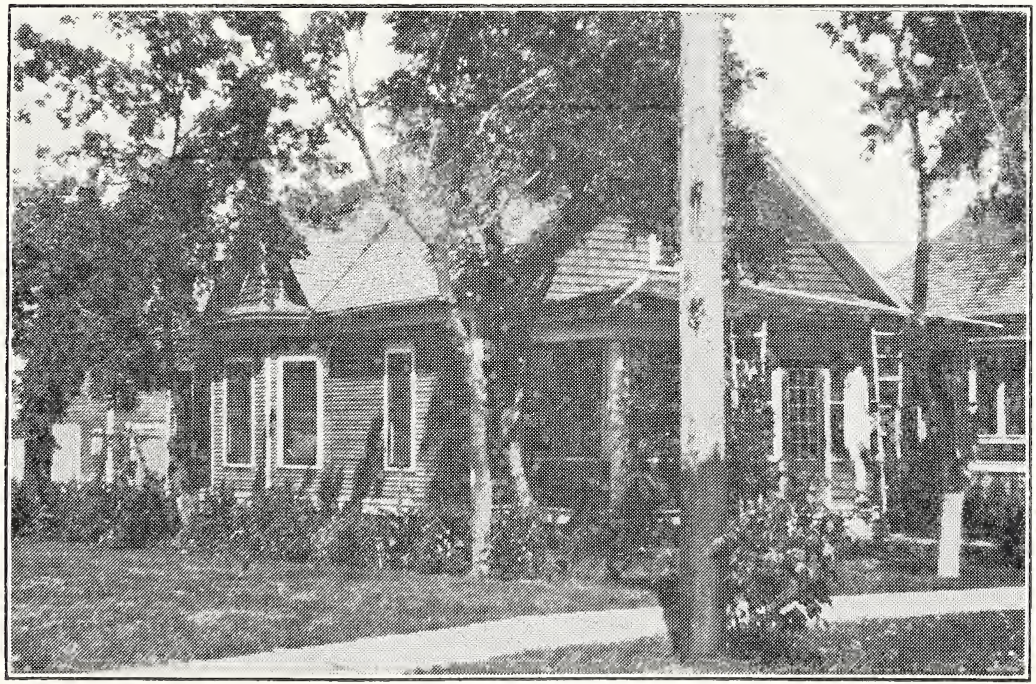




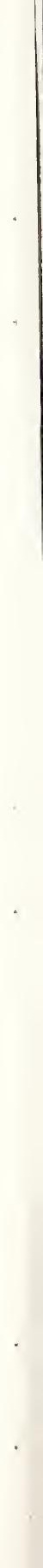


ize the buildings with the shrubbery and trees. The object desired in home grounds is to give the house and other buildings, which are not natural to the ground, a perfectly comfortably setting, so they will look cozy and homelike. This requires a careful planting of shrubs and vines around the walls of the house, so that it will have something tieing it to the ground, as it were. Here, again, beware of shutting yourself in, while shutting out the public. The planting along the side of the house effectively breaks the line between the house and ground. Here, as in the border, avoid straight lines. Do not plant the tall growing plants in front of the windows. If planting for winter effect as well as summer, there are many forms of evergreens, especially the dwarf varieties than can be used in the beds in front of the walls. All shapes and sizes may be had to suit the style of architecture.

The varieties of shrubs are so many that the amateur may well be puzzled when it comes to selecting what is needed. A succession of bloom may be had for about eight months of the year, while during the other four months the red, yellow and green twigs of some shrubs and bright berries of others will tend to liven the dreary landscape.

The commonest mistake of all is to have too great a variety of shrubs on a small lawn. It is far more effective to have a clump or mass of one kind of bloom than to have single specimens.

Another mistake that is frequently made is to use too many plants with highly colored leaves, such as Purple Leaved Plum, variegated or Golden Leaved Elder, etc., or too many weeping trees.

\section{Hardy Perennials}

One of the essentials in securing a bright and lovely garden or border is color, and to get this you need perennials. Most of the shrub planting is to secure foliage, the quiet green against the house foundation or along the border lines. In order to secure a succession of color from spring until fall liberal use should be made of perennials. Their range of height, foliage, color and time of blooming is so varied that they are really indispensible. The perennial is a plant with a hardy root system which lives in the ground from year to year while the top dies back in the late fall. They thrive best in moderately rich soil not too wet. It is well to cultivate deep in the preparation of the ground so that the root growth will extend far below the surface and eliminate the need of watering. After the ground has frozen a few inches they should be mulched with leaves, straw, coarse manure or clean litter of any kind and this should be left on for a time in the spring to prevent freezing and thawing, which is very injurious to the young shoots. After the danger of frost has passed it can be raked from the plant and worked into the soil or left on top as a mulch to conserve the moisture. In selecting perennials care should be exercised to provide, not only a liberal contrast in the color scheme, but also a succession of bloom from spring until fall. The following list covers a range sufficient for all purposes.

ACHILLEA, Millefolium-Rosy pink flowers in dense heads on stems eighteen inches high. Effective on edge of shrubbery or in border. July to October. 
ACHILLEA, The Pearl-Pure white double flowers borne freely in clusters. Very effective to soften conflicting notes in the color scheme. I5 to 24 inches. All summer.

AURUNDINARIA, Variegated Grass-Beautiful for inside borders. Striped flag-like leaves of white and green. I 8 inches.

BABY'S BREATH, Gypsophilla-Dense spreading symmetrical foliage covered with minute white flowers having a beautiful gauze-like appearance. 2 to 3 feet. July and August.

BLEEDING HEART-Have long racemes of pink flowers which are always attractive. Come up early in the spring and flowers inmediately. 2 feet. May to July.

CHINESE LANTERN FLOWER-A quaint salmon shaded bell-like flower. Excellent for winter bouquets. Very hardy. Easy to transplant. Very desirable. Grows to a height of about 2 feet. Flowers bear in September.

CANTEBURY BELL, Campanula--An old favorite with beautiful bell flowers in pinacles, blue to white. Protect heavily in winter. I8 to 24 inches. June and July.

COLUMBINE, Coerulea-They come in assorted colors of blues, whites, yellows, pinks and rose. Grow in almost any soil but prefer well drained sandy loam. I 2 inches. April to July.

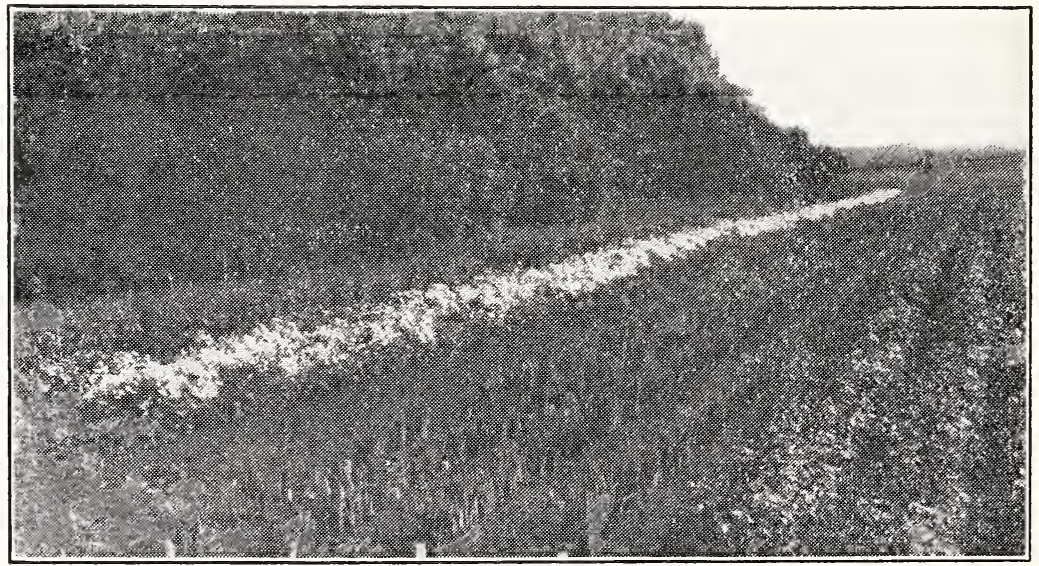

A Block of Perennials 
COREOPSIS LANCOLATA-An improved variety with large bright yellow flowers, one of the best hardy plants. Fine for cut flowers. 20 inches. June to October.

DIANTHUS PLUMARIUS-The hardy pinks have a spicy fragrance without which the garden is incomplete. Their perfect form and rich coloring make them great favorites for summer bouquets. Io inches. June.

FOX GLOVE, Digitalis-A biennial which under proper conditions will seed itself. Very attractive in the border. Sold only in assorted colors but are mixed from the best plants. 2 to 3 feet. June to July.

GIANT DAISY, Pyrethrum-A hardy tall growing plant throwing out long stems which bear clusters of pure white flowers with yellow centers. Blooms late in the summer and continues until frost.

GAILLARDIA, Grandiflora--The flowers are of gorgeous coloring. The center is of dark red-brown, while the petals are marked with brilliant crimson, orange and vermillion and often a combination of all in one flower. I5 inches. All summer.

GOLDEN GLOW, Rudbeckia-Has wide and striking range of foliage and an abundance of double yellow-golden flowers, shaped like a cactus dahlia. 5 to 6 feet. July and August.

HELENIUM, Dutumn-Late bloomer. Flowers of a rich deep cream, foliage dark green. Similar to the Riverton Gem except in color. 2 to 3 feet.

HELENIUM, Hoopsi-A dwarf variety, very hardy. Flowers of a deep yellow. Foliage very coarse, dark green. I4 inches. June.

HIBISCUS, Mallow Marvels-A robust type of upright habit, producing an abundance of flowers of enormous size in all the richest shades of crimson, pink and white mixed colors. 4 to 5 feet. August and September.

HOLLYHOCKS-These stately majestic plants are as old as the country, but the double sorts are not so well known. We have them in double pink, double white, double cream, also assorted colors in both double and single. 6 to 8 feet. June to September.

$$
\text { Oslo, Minn., May 22, } 1925 .
$$

Gentlemen: Well, it is all over for this spring. You have certainly done much more than I had expected to help me and to please the customers. I have not had one person tell me yet that they are not more than pleased with the way you have treated them. The size of the apple trees and that extra bunch of snowballs you sent, are great factors in making friends for you and for me.

I want to thank you here for the splendid way you have helped me. I am sure it will help me in the future. I see now that I can compete with any of them. 
LARKSPUR, Delphinium BelladonnaMost continuous bloomers of all Larkspurs, with delicate, clear turquoise blue flowers. I8 inches. June and July.

LARKSPUR, Chinese-A dwarf varicty with fine feathery foliage and deep genetian blue flowers. 2 feet. July and August.

LARKSPUR, Chinese Album-A form of the above with pure white flowers. 2 feet. July and August.

PERENNIAL SWEET PEA, LathyrusAn exceedingly hardy and interesting plant adapted for wild tangles or rookery worknever in the border. The flowers are clustered, of assorted colors, very odorous and borne profusely. Fine for a trellis or fence. June to September.

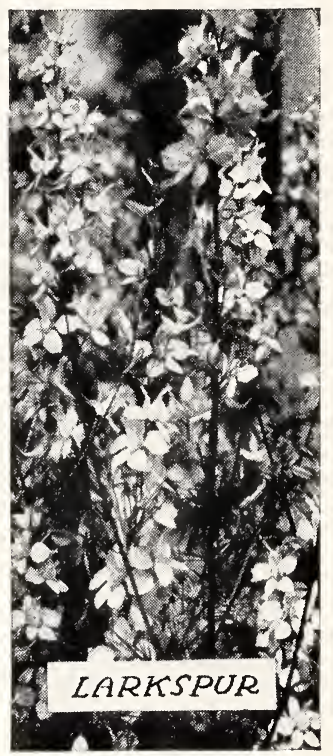

LILY-OF-THE-VALLEY, Majalis-The daintiest and most lovable of all garden herbs. Flowers pure waxy white and in graceful drooping racemes. 6 inches. May.

MONARDA, Didgma-Second only to the Cardinal Flower in the intensity of its crimson flowers. Rather coarse and aromatic. Most effective at a distance. 20 to 30 inches. June to August.

PHYSOSTEGIA, Virginianna-Used for border with striking effect. Flowers one inch long in white, rose and purple. 2 to 3 feet. July and August.

PLATYCODON, Grandiflora-Old fashioned flowers of the garden, very regular in growth and habit. Large showy deep blue flowers. I8 inches. June to October.

PLATYCODON, Grandifiora Alba-Same as the Grandiflora except that it has white flowers.

POPPY, Orientallis--Enormous fiery red flowers six to eight inches across with a satiny crimpled texture and peculiar hairy stems. Effective for use with shrubbery. 2 to 3 feet. May to July.

PYRETHRUM, Hybrid Single-Flowers are variegated and are borne on long stems, most convenient for decoration. May and June. June. 
SEDUM, Acre-Foliage, green creeping flowers in yellow masses. Much used for covering graves. 3 inches. June to July.

SEDUM, Seiboldi-Pink flowers and slender purplish branches. A very popular variety, I8 to 24 inches. August and September.

SEDUM, Spectabilis-One of the prettiest erect growing species, attaining a height of eighteen inches, with broad, light green foliage and immense heads of showy rose colored flowers. August to October.

SHASTA DAISY, Medium-A practical creation of Luther Burbank that is deserving of greater use. Flowers of pure glistening white, adapts itslf to any soil or location. Excellent for cut flowers. I8 inches. June to September.

STATICE - A fine foliaged perennial, with a misty profusion of blue flowers. Splendid for winter bouquets.

SPIREA, Filipendula-Low tufted plant with double white flowers and fern-like foliage. Hardy and thrive in any soil. I2 to I 8 inches. June and July.

SWEET WILLIAM, Barbatus-One of the best and most satisfactory of the old fashioned plants. We furnish them in assorted colors of an endless variety. I5 inches. June and July.

THOUSAND-TO-ONE-ASTER, Boltonia--A hardy native perennial that has been propagated for years. Large aster-like flowers of pink, slightly tinged with lavender. 4 to 5 feet. June to September.

TRITOMA, Pfitzerii-A choice border plant of free blooming qualities and a peculiar flower, rank. Scarlet to orange. Must be taken up in winter. 2 to 3 feet. August to October.

VERONICA, Longifolia-One of the handsomest blue flowering plants. Spikes completely studded with blue flowers. Fine for cutting and one of the best plants for the hardy border. 2 feet. July to September.

YUCCA, Filamentosa-A very striking plant of tropical appearance. A stiff clump of sword-like leaves is surmounted by a stalk of beautiful creamy white bell-shaped flowers. Well adapted to isolated positions on the lawn or on dry banks where other plants do not thrive. 5 to 6 feet. June and July.

\section{Phlox}

As a perennial the Phlox ranks high among the most permanent and satisfactory. The foliage is good during the entire summer and the flowers range in all shades from white to deep red and purple and last from July to October. The flower is best adapted to massed planting either in beds or along the border. Set Phlox in a warm sunny place 
in deep rich soil. On account of the long blooming season the Phlox is a heavy feeder and should have frequent fertilization and cultivation. The following list is recommended for beauty and hardiness:

Pluton-Red.

Peach Blow-Late pink.

Jean De Arc-Late tall white.

Pantheon-Pink.

Champ Eysee-Red.

Richard Wallace-White, pink center.

Nemaha-Dwarf white.
R. P. Struthers-Pink.

Mrs. Lingard-Early white.

Rynstrom-Pink.

Mrs. Jenkins-White.

Eclaireux-Purple.

Van Lassburg-White.

Mrs. Chas. Dorr-Light purple.

\section{Peonies}

There is no flower today that has so many real admirers in America as the Peony and no flower that is so universally grown. There are thousands of people who grow large blocks of peonies of many varieties purely for the pleasure and recreation they get out of it, in fact the "Peony Fan" is getting to be about as numerous as the "Sport Fan." No matter how large or small the flower garden, it seems the Peony must be there with its rugged dark green foliage and massive yet delicate blooms to complete the picture. Not only is this true but the Peony will stand more abuse and neglect than almost any other flower and yet serve well its master. Of course no one wants to abuse anything so grand and beautiful as a Peony and if you will give them the ordinary soil and care that you would any other flower you will be delighted with the results and well repaid for your efforts. Plant Peony roots in

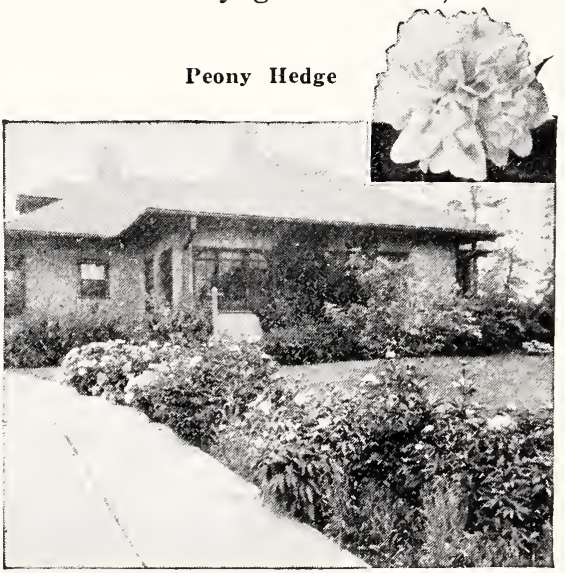
good rich, well drained soil, from two to three feet apart each way. Cover with three, or not over four inches of loose dirt and pack well. If planted too deep they are liable not to bloom and if too shallow the frost is very apt to heave the crown eyes out of the ground and kill them. Give them plenty of water just before blooming time. In the fall cover the bed with about two inches of coarse manure and in the spring rake it away from the plant and work into the soil. As the plants become well filled after three or four years take up the roots early in September and divide them, leaving three or four good crown eyes to each division. These should be planted at once in a different location, or if planted in the same place it is best to dig out the old earth around the plant and fill in with new. Do not be discouraged if 
your blooms are not what you expected the first and second year as Peonies seldom bear true to type during the first two years. Wait until the third year and you will know exactly what you have. The following list will give you a wide range of colors from which to select.

Alexander Dumas-Pink and Golden Harvest-Cream light cream.

Chas. McKillup-Crimson. low.

Couronne D'Or-White and yel-

Delachei-Red, gold center.

Delicatissima-Pale pink.

Duchess De Nemours-White, lemon center.

Eugene Verdier-Pale pink and cream.

Felix Crusse-Red.

Festiva Maxima - White, red blotches. pink border.

Karl Verdier-Rose.

Louis Van Houtti-Red.

Madam Crousse-White.

Meissioner-Red.

Mons Jules Elie-Lilac pink.

Princes of Darkness-Dark mé.. rooil, gold center.

Richardson's Rubra Superba-

Fringe Leaf-Red, gold center. Late, red.

Richard Carvel-Bright crimson.

\section{Bulbs for}

The hardy spring blooming bulbs form one of the most valuable of the garden's assets. There are so many varieties of them and so many of them of such simple culture that the least experienced need not hesitate to undertake the growing of them. The most satisfactory soil for growing bulbs is a fibrous loam, well supplied with sharp sand and it should also possess good natural drainage. They should be planted only in the fall in order that their roots may become established for the very early bloom. After the ground is frozen mulch the bed with clean straw or litter and rake away early in the spring. Do not use fresh stable manure at any time, either in the soil or as a mulch or you will have no flowers. An ideal way is to plant in irregular patches at the edge of the shrubbery, borders or about the lawn beneath

\section{Fall Planting}

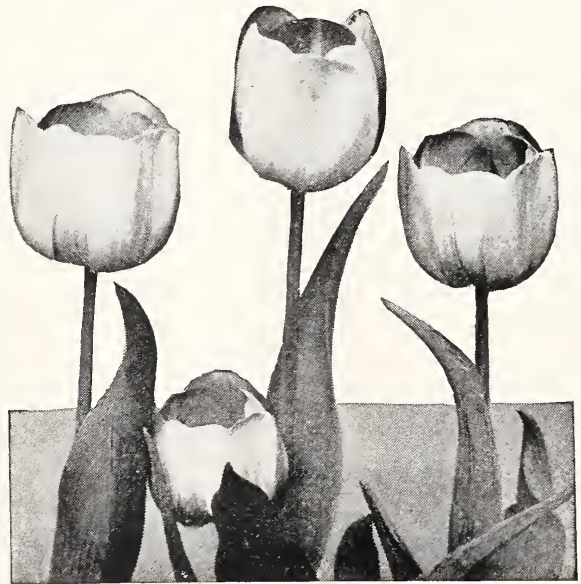

Tulips 
the trees. Beds may be used and definite color schemes worked out. A thin layer of sand upon which to lay the bulb will well repay for the trouble. The accompanying diagram shows the depth to plant the different bulbs.

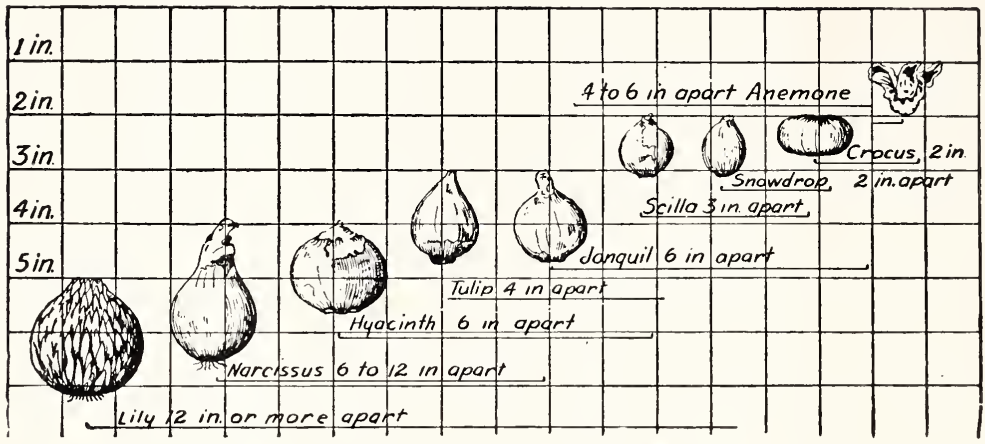

\section{Tulips}

The tulip in spring brings a wealth of colors and shades of a wonderful richness in texture. The early tulips, both double and single, begin to flower in April. We have selected what we think to be the best varieties of the different colors.

\section{EARLY SINGLE}

Artus-Splendid deep scarlet.

Chrysolora-Golden yellow, fine bedder.

Duchess de Parma-Orange- scarlet, yellow edge.

La Reine-White, shaded rose.

Rose Gris de Lin-Delicate rose, flushed with white.

\section{EARLY DOUBLE}

Brimstone Beauty-Yellow and apricot.

Gloria Solis-Bright scarlet, yellow border.
Murillo-Large pink, suffused white.

Rubra Maxima-Dazzling white.

Schoonoord-Pure white, extra fine.

\section{DARWIN TULIPS}

The Darwin Tulips are beautifully outlined, cup-shaped and carried on tall, stiff stems, 18 to 24 inches in height. They bloom in May.

CLARA BUTT-Bright shrimp pink, paler edges.

INGLESCOMBE YELLOW--Full rich yellow.

KING HAROLD-Deep purple red with white base.

SIERRAD VAN FLORA-Bright red, blue base. 


\section{Narcissus or Daffodills}

The varieties in our list have been carefully chosen from the large number of varieties grown abroad and have been thoroughly tested.

ALBA PLENO-Double white.

PRINCEPS-Trumpet yellow.

\section{Hyacinth}

A bed or border of Hyacinth proves attractive to every beholder. With their brilliant colors and delightful fragrance together with their long keeping qualities and decorative appearance they command a valuable place in every home and garden. Good enriched soil and extra care will be appreciated and repay many fold. We furnish them either assorted or in the following colors: Blue, red, pure white and pink.

\section{Crocus}

One of the earliest flowers to open in spring, the Crocus makes an effective show when planted in masses or where three or four rows are arranged in the border. They are perfectly hardy and can be left in the ground for several years without being disturbed. They come assorted in many varieties and shades of white, yellow, lavender and purple.

\section{Bulbs for Spring Planting}

To bring beauty during late summer and fall when most of the earlier flowers have come and gone there should be a liberal planting of Dahlias, Cannas and Gladiolus. They will help round out the season in a pleasing way. They cannot be treated as other bulbs or perennials as frost is fatal to the tubers. Dig them up in the fall before the ground freezes and after they have been thoroughly dried and cleaned store them in a cool, dry part of the cellar in shallow boxes.

CANNAS-A wonderful bedding plant, very bold and striking in appearance. Does well in almost any soil but responds quickly to good care and fertilization. Plant two feet apart and three to four inches deep. We have selected the following varieties which we consider best suited for general planting

Mrs. Alfred Conrad--Pink.

Wintzer's Colossal-Red.

King Humbert-Red.

President-Red.

Florence Vaughn-Bright yellow.

DAHLIAS - Very showy for late bloon, in a great variety of colors. For ordinary planting we suggest mixed varieties. If special colors are wanted, order by name. Somewhat injured by drought and should be watered during dry seasons. Plant not closer than 18 inches apart and 3 inches deep.

Autumn Chief-Bright red.

Crimson Beauty-Bright carmine

Curban Giant-Red.

Cycle (Cactus)-Red.

Dracut-Purple.

Dreer's White-White.

Jack Rose-Red.

Janet-Red.

Milwaukee-Red.

Oban--Variegated.

Sylvia-Rose.

Queen Victoria-Yellow.

Soru de Gustav Duazon-Orange

Storm King-White. 
GLADIOLI-It is certain that no flower can give so great beauty for so little expense and labor as a good collection of Gladioli. They are easily grown and the bulbs can be used for years if they are carefully stored as explained above. They make beautiful cut flowers for the house during the late summer and fall. Bulbs should be planted four inches deep in good mellow soil. Order either assorted or special named varieties.

America-Pale pink.

Assorted-All colors.

Black Hawk-Cardinal red, black blotch.

Chris-Dark maroon.

Empress of India-Purple.

Fairfax-Purple.

Halley-Salmon pink.

Heley Franklin-White, violet markings.

Hohenstouffen-White. center.

Jesse-Rich velvety red. red.

Maiden Blush-Pale cream.

Marshall Foch-Rose pink.

Mrs. W. E. Fryer-Blood red.

Mrs. Frances King-Red.

Mrs. Whitney-Yellow, light

Peace-White.

Pendleton-Pink, blotched with red.

President Taft-Pink.

Primanulis-Yellow.

Schwaben-Yellow. markings.

War-Dark red.

White Giant-White.

Wilbrink-Light Pink.

Willie Wigman-White.

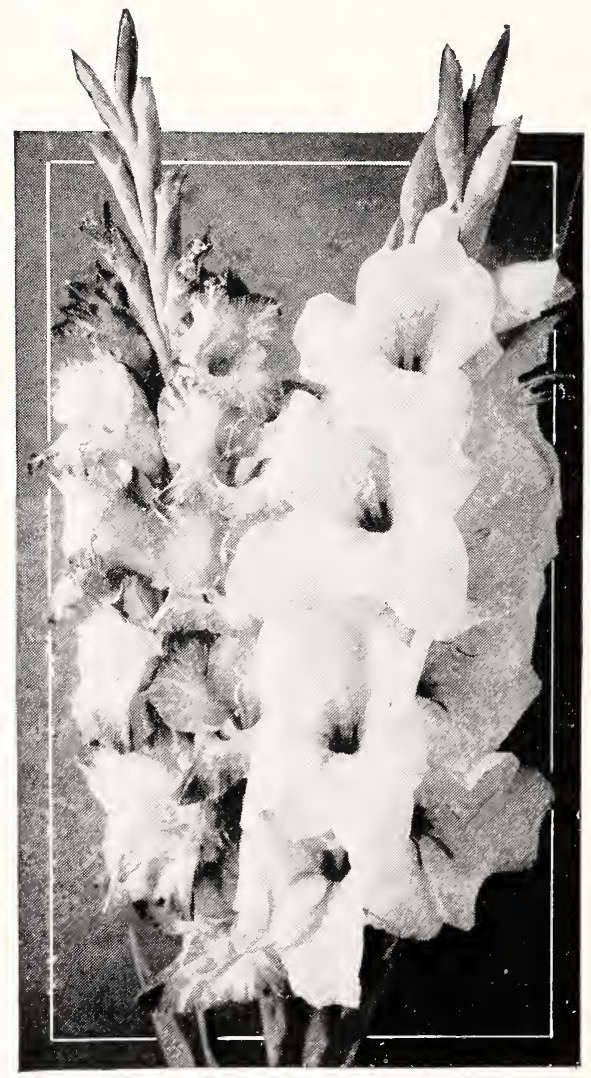

\section{Plan to Plant Another Tree This Year}




\section{The Iris}

GERMAN IRIS-Can be grown in any kind of soil successfully but it loves a moist situation best. They are in bloom usualy before Memorial Day and the flowers cover the most expisite tints and colorings. We believe we have one of the finest assortments of this popular plant to be found anywhere.

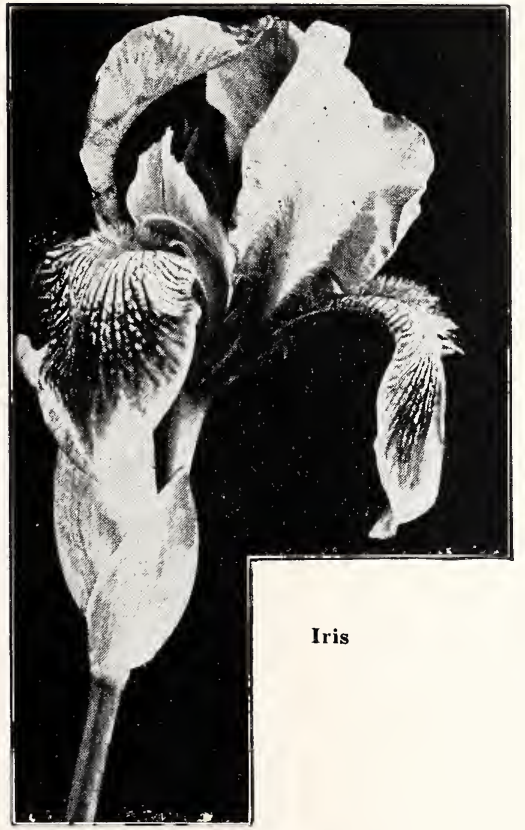

Dot Clark-White and violet.

Flavescens-Cream and white.

Floret White-White.

Gertrude-Violet.

Her Majesty-Pink.

Honorabilis-Yellow and brown.

John De Witte-Light purple.

Lord Grey-Light cherry.

Lord Wolesley-Light purple.

Madam Chereau-Violet.

Prosper Langier-Bronze a n d red.

Queen of the Gypsies-Red.

Rhein Nixe--White and purple.

JAPANESE IRIS-This should not be confused with the German Iris, as they are an entirely different strain. It blooms a month later, has a much larger flower, but is not so free a bloomer. It makes up in size and intensity of coloring what it lacks in abundance of bloom.

Snow Queen-White.

Blue King-Purple.

Superba-Dark Purple.
Fairy-Purple.

Japanese-Sky blue.

SIBERIAN IRIS-These are a Siberian varicty of extreme hardiness. They are the latest to bloom of all the Iris family.

Alba-White. Gravet-Violet and light blue. 


\section{Lilies}

Although the lily is one of the most stately and attractive of all the blooming garden plants they seem to be also the least understood and appreciated. The ornamental value of the lily lies almost entirely in the flowers as they are of scant foliage and of a character altogether foreign to the usual blending of parts. Most lilies are heavy bloomers and are very striking in color and should be grouped against a strong green background for the best effect. They love warm sun but their bulbs will not stand hot baked soil. The soil most desirable is a loose sandy loam which will be enriched by a top dressing of manure and should be well drained. They should be sheltered from the wind and if possible be shaded at noon. Keep bulbs from undue exposure to air and plant in the spring about six inches deep. Winter mulch

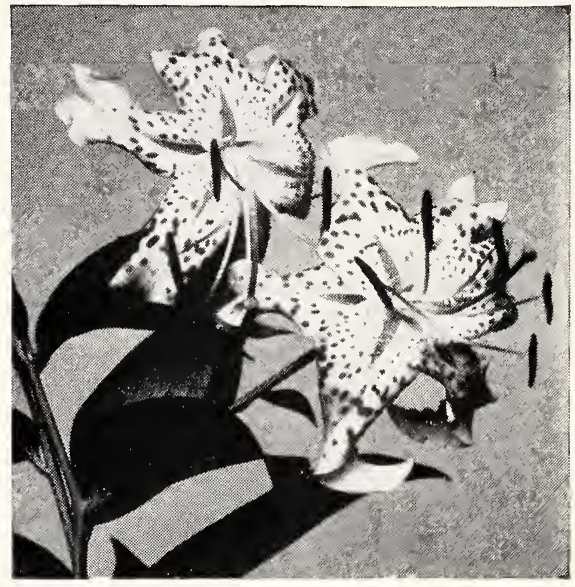

Lililum Tigrinum

always pays. Never allow manure to come in direct contact with the root bulbs. They may be left in the ground from year to year. The following list gives a wide range of color from which to select and are fectly hardy.

Auratum-White, dotted with

Coerulea-I.ight purple.

Day Lily-Orange.

Green Leaf Funkia-Purple.

Lilium Candidum-Pure white.

Lilium Elegans-Red.
Rubrum-White, spotted with rose red.

Tiger Lily-Orange, spotted with black.

Tigrinum-Orange, dotted with crimson.

REGAL LILY - The new outdoor Easter Lily. The only lily that will successfully winter in the ground. Introduced in 1910 by Mir. E. H. Wilson, from Northern China. It is rapidly gaining in popularity. Its flowers, in shape, like the old well-known Easter Lily, but with a faint pinkish tint that seems to liven up the whole flower. Delicately fragrant. Sturdy. It deserves a place in every yard.

\section{Its Not a Home Until Its Planted}




\section{Roses}

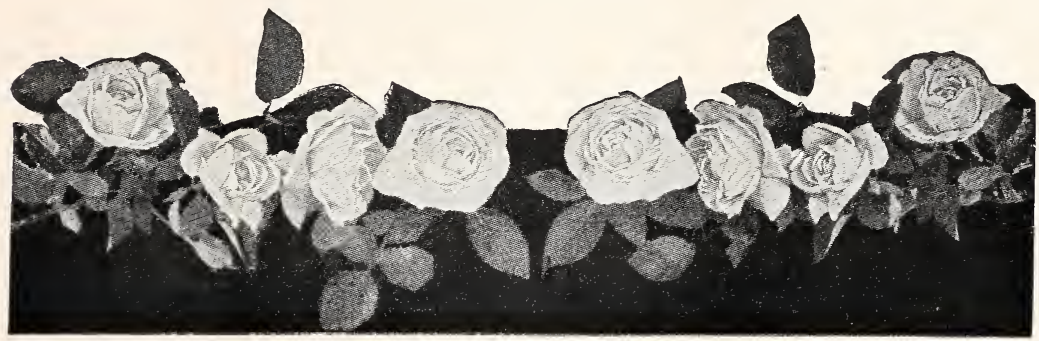

The rose has truly been christened the "Queen of Flowers." There is no flower so beautiful, so fragrant and so universally loved and appreciated as the rose. Originally the rose was considered more of a tropical or hot house plant, but with the introduction of the many varieties of Hybrid Perpetual Roses, horticultural science has made it possible for the Northwest gerdener to enjoy as wide a variety and as beautiful roses bed as our Southern neighbors. These Hybrid Roses, crossed between the June and Monthly roses, retain not only the hardiness of one parent but also the perpetual blooming habits of the other. As all hybrid roses bloom on new wood only they should be cut off to about eight or ten inches above the ground each spring and they will send up good strong shoots that will produce much larger blooms than will the weak slow growth from the old wood if left untrimmed. Clipping of the seed pods is also an aid in the blooming. When setting out new plants, make the ground rich with well rotted manure well worked in and dig the holes large enough so that the roots will not be crowded. Cut new plants down to about six inches from the ground and water liberally when planting. They should be kept well cultivated until about July Ist and then well mulched with straw or lawn cuttings. Spray with lime-supher for fungus and with arsenate of lead for slugs and caterpillars. All hybrid perpetual roses need winter protection. This can be easily done by throwing up a mound of earth around the plants about twelve inches high before the ground freezes and after the ground is frozen cover the bed with branches or coarse corn stalks to hold the winter snows. After the frost is gone in the spring remove the litter and earth and cut back at once. The following lists are grouped as to color to make easy selection and are recommended for hardiness.

\section{HYBRID RUGOSA ROSES}

These new hybrid rosa Rugosas can be grown anywhere in Minnesota or the Dakotas without winter protection. They are a wonderful addition to the rose family being exceptionally free from worms and 
disease. They grow to four or five feet high, start blooming early and continue through summer to late fall, furnishing an abundance of cut flowers the entire season. They make the most beautiful flowering hedge known.

Blanche de Coubert-Double white.

Belle Poitevine-Double deep pink.

Conrad F. Meyer-Double pink.

Grootendorst-Double bright crimson.
Hansa-Double red.

Sir Thos. Lipton-Double white.

New Century-Double rose pink.

Single Red.

Single White.

Single Pink.

\section{HYBRID PERPETUAL ROSES}

RED

American Beauty.

General Washington.

General Jack.

Gruss en Teplitz.

Louis Van Houttii.

Marshall P. Wilder.

Prince Camille de Rohan.

Ullrich Brunner.

Amelia Grovonaux.

Captain Hayward.

J. B. Clark.

YELLOW

Harrison Yellow.
Persian Yellow.

Soliel D'Orr.

WHITE

Frau Karl Druschki.

Mable Morrison.

Margaret Dickson.

Madam Plantier.

PINK

Anne de Diesbach.

John Hopper.

Mrs. John Laing.

Magna Charta.

Paul Neyron.

\section{CLIMBING ROSES}

Climbing roses should be trimmed back sparingly after the first year and need not be covered during the winter. Spray same as hybrid perpetuals.

WHITE

Dorothy Perkins.

Baltimore Belle.

White Pambler.

PINK

Dorothy Derkins.

Pink Rambler.

Prairie Queen.

Seven Sisters.

Paul's Scarlet.
RED

Crimson Rambler.

Climbing American Beauty.

Excelsa.

Flower of Fairfield.

Tausendschoen.

Single Red Climber.

TEA ROSES

Baby Rambler: Red

Pink

White 


\section{Climbing Vines}

Climbing vines play a very important part in all landscape planting. With them many a stone wall or unsightly back yard fence can be transformed into a pleasing background for inside planting. Brick, stone or stucco walls of the home which look bare and brazen may be softened and beautified with climbers. The flowering sorts should be well cared for the first year and the earth thrown up in a mound at the trunk to prevent water standing around them. Cut worms sometimes work havoc with the young tender sorts but this can easily be prevented by removing both ends of a good sized tin can and pressing it down over the plant; wood ashes are also very effective.

AMPELOPSIS, Englemanii-Short jointed with fine foliage. Clings to brick or stone. A good grower and very hardy. The best for the north and northwest. Foliage beautiful red in fall.

AMPELOPSIS, Veichii-Very graceful, but of delicate habit. Thrives best in shaded position. Clings perfectly to smooth, hard surfaces. Foliage dark green, changing to orange and red in fall.

AMPELOPSIS, Quinquefolia-The old original Virginia Creeper, sometimes called Woodbine. It is an extremely rapid grower. Leaves are deeply cut and turn to a beautiful shade of red in the fall.

BITTERSWEET-A native climbing or twining plant with fine, large leaves. Yellow flowers and clusters of orange, capsuled fruit. It grows ten to twelve feet in a season.

CLEMATIS, Henryi--New and one of the best perpetual hybrids, of robust habit. The flowers are white, large and very showy.

CLEMATIS, Jackmanii-Flowers from four to six inches in diameter, intense violet-purple with a velvety appearance, very hardy. A free grower and often blooms from midsummer until frost. Fine for porch or trellis.

\section{CLEMATIS, Madam Ed} Andre-Flowers large and of a beautiful wine color. Free flowering and continuous bloomer.

CLEMATIS, PaniculataA great novelty from Japan. It has proved to be one of the most desirable, useful and beautiful of all hardy vines. A luxuriant grower and profuse bloomer. Small, white fragrant flowers in September. Useful for covering verandas, pillars or fences where a trellis or support can be provided. Makes a growth of twenty to thirty feet in a single season and should be cut back to the ground each season.

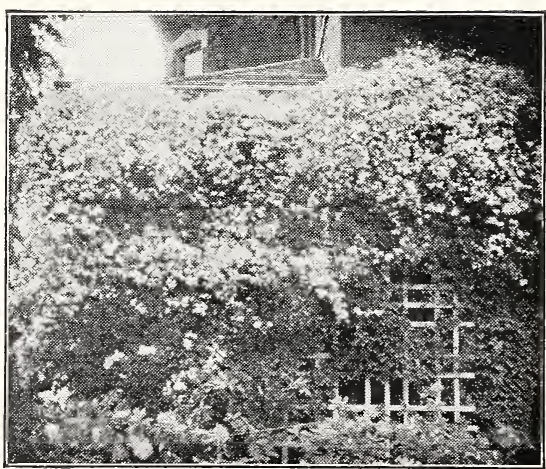

Clematis Paniculata 
CLEMATIS, Coccinea-A very handsome hardy climber, bearing small, thick, bell-shaped flowers of bright coral red, in wonderful profusion from June until frost. Its small shiny foliage is very ornamental.

CLEMATIS, Ramona-One of the large flowering varieties, similar to the Jackmani except that the flowers are of a deep sky blue. Hardy and prolific.

CLEMATIS, Virginiana-A remarkably rapid climbing plant, growing to the height of twenty feet producing a profusion of white flowers in August.

DUTCHMAN'S PIPE-A vigorous and rapid growing climber, with yellow-brownish flowers resembling a pipe in shape. Fine foliage of light green leaves of large size which retain this color from spring to fall.

HALL'S JAPANESE HONEYSUCKLE- $A$ strong, vigorous, almost evergreen sort, with pure white flowers changing to yellow. Very fragrant and covered with flowers from July to November. Holds its leaves until January.

HONEYSUCKLE, Climbing Scarlet Trumpet-Semi-evergreen, scarlet flowers followed by berries of the same hue. A special favorite with all lovers of old fashioned flowers.

MATRIMONY VINE-Produces a large number of purple flowers which are succeeded by bright scarlet berries almost an inch long. It blooms throughout the summer and the fruit remains on the vine until late in winter.

WISTERIA-One of the most rapid growers of all the climbing plants. Grows fifteen to twenty feet in a season. Has long pendulous clusters of pale blue flowers in May and June and sometimes in autumn.

\section{Flowering Shrubs}

There is nothing that can add more to the beauty of the home than to have the sides and background well filled with nicely arranged groups of shrubbery. By a judicious selection of varieties a succession of bloom may be had from early spring until late fall. The flowers may be had in many forms and in going over the following list it will pay to make some attempt at following out a blooming scheme. Shrubs, for best results, should not be scattered about the lawn, but massed in irregular groups against the buildings, in the corners and at the back and sides of the lawn. This is done to leave broad areas of light and shade which is essential. Flowering shrubs should be cut back severely at planting time, leaving not over eight inches to a foot above the ground. They do better when kept well trimmed each year, but this should, unless otherwise noted in the description, always be done after they are through blooming, never in the spring if you want them to bloom, as spring trimming takes away the flower buds. Mulching and spraying always pays.

ALTHEA-Large double or single flowers in richest shades of rose and purple or white. Prune heavily in March for bloom. 6 to Io feet. August and September. 
CALYCANTHUS-Admired for the spicy fragrance of their leaves and peculiar attractiveness of the blood-brown flowers hidden away among the broad shining leaves. Succeeds in shade. 3 to 6 feet. May and June.

COTONEASTER-An attractive, beautifully formed shrub with thick, glossy leaves, turning to red in the fall. Small white flowers in early summer followed by large black berries which remain on the bush nearly all winter. Perfectly hardy. 8 to io feet.

CRANBERRY, High Bush-Handsome native shrub. Flowers white in flat clusters, followed by bright scarlet berries which hang to the bush through the winter. 8 to I 2 feet. May and June.

CURRANT, Alpine-Dense and upright. Yellow bloom. Excellent for dry sterile soils and under planting. Foliage beautiful. 3 to 5 feet. May.

CURRANT, Yellow Flowering-Very hardy and has a profusion of vellow fragrant flowers followed by brownish fruit. Does well in shady locations. 5 to 6 feet. May.

CRAB, Double Flowering-Tree of medium size covered with double fragrant flowers of delicate pink to white. Hardy and blooms when quite young. I5 feet. May.

DOGWOOD, Lutea-A yellow branched form of the Stolonifera, used very effectively for contrasting. 6 to ro feet. June.

DOGWOOD, Siberica--Blood red branches. Grows in great tangled masses when mature. Flowers yellowish white, fruit pearly white. 5 to 8 feet. May and June.

DOGWOOD. Variegated-Fine variegated leaved shrub, of rapid growth and valuable to plant singly or in groups. Leaves are distinctly variegated, white and green. 4 to 6 feet. May and June.

DOGWOOD, Sanguinea-Handsome wide growing shrub, with deep red or purplish branches. Black berries. 6 to $\mathrm{I} 2$ feet. June.

DOGWOOD, Stolonifera-A hardy shrub with bright red bark in winter. White flowers in flat clusters. White berries. 6 to ro feet. June.

DEUTZIA. Rosea-Large growing type with pink flowers. Not very hardy and liable to freeze back in winter. 3 to 5 feet. June.

DOUBLE FLOWERING ALMOND-A low shrub. upright in growth and one of the most spectacular in early spring. Blooms early and profusely. We have them in red, pink and white. 3 to 5 feet. May.

ELDER, Common-A large rapid growing shrub with immense flat clusters of white blossoms in early summer followed by black berries which are often used for pies, etc. 8 to 22 feet. June and July.

ELDER, Cut Leaved-A strong grower with elegantly divided foliage. Does well in shaded locations. 8 to ro feet.

ELDER, Golden-A beautiful rapid growing shrub, with bright golden foliage, the metalic luster of which is relieved in season by masses of white bloom. 6 to 8 feet. June and July. 
ELDER, Red Berried-Blossoms white, produced in great profusion followed by bunches of red berries. Bush vigorous and hardy. 8 to I 2 feet. April and May.

FORSYTHIA, Fortuna-An upright spreading bush with handsome pendulous trumpet shaped, bright yellow blossoms. Foliage deep shining green. Not exceedingly hardy. 6 to 8 feet. April and May.

FORSYTHIA, Suspensa-Slender arching branches lapping over on the ground. Flowers striped with yellow. Useful for banks and walls. Needs winter protection. 6 to 8 feet. April and May.

HONEYSUCKLE, Tartarian-One of the most popular ornamental shrubs. Very hardy, large growing, easily transplanted and does well in any soil. Abundant foliage and delicate flowers, followed by red or yellow berries. We grow the red, pink and white; state color wanted. Does not need much pruning. 8 to I 5 feet. May and June.

HONEYSUCKLE, Morrowi-A Japanese variety. Remarkably fine plant with wide spreading branches. Yellow flowers, followed by red berries during the latter part of the summer. Leaves remain late in fall. 4 to 6 feet. May and June.

HONEYSUCKLE, Tree-Same as the Tartarian only trained to tree form. Valuable for use in mass planting. Io to 20 feet. May and June.

HYDRANGEA, Paniculata Grandiflora-A most valuable shrub. Medium size with fine large foliage and immense trusses of white flowers, changing to pink and finally reddish brown. Bushes transplant very easily and usually bloom the first year set out. Plant singly or in groups. Bushes should be trimmed back severely each spring to get nice large flowers. 3 to 6 feet. August to September.

HYDRANGEA, Arborescens-A vigorous upright shrub with creamy white flowers in flattish clusters. Foliage finely finished. Excellent for grouping with other shrubs as it blooms after most of the others are through. 4 to 6 feet. June to August.

HYDRANGEA, P. G. Tree Form-A very striking specimen and particularly adapted to use on small lawns. Spreading head with beautiful flowers. 6 to 8 feet. July to October.

BUTTERFLY BUSH-Sometimes called the summer lilac. The violet colored blossoms are borne in terminal panicles and one bush will often attract hundreds of butterflies. Fragrant and showy. 3 to 6 feet. Late summer.

JUNEBERRY - A high growing tree-form shrub with drooping racemes of feathery, pure white flowers. Berries resemble blueberries in both appearance and taste. Io to 20 feet. May.

JUNEBERRY, Dwarf-More or less compact in growth with beautiful foliage and pure white flowers. 5 to 7 feet. April and May.

LILAC, Chas. X-Very hardy. This variety is a grand improvement over the common purple. Flowers reddish purple, one-half larger and more abundant. 8 to Io feet. May and June.

LILAC, Common Purple-A very hardy, large growing shrub, with purple flowers. Much used in hedges and individual planting. 8 to I2 feet. May. 
LILAC, Common White-Of rapid growth, with large shining foliage. Produces large clusters of fragrant white flowers. 8 to Io feet. May.

LILAC, Frau Dammann-A popular new variety with fine foliage and large single white flowers. 6 to 8 feet. May.

LILAC, Josica-A distinct sort of tree like habit, producing purple Howers when most other have ceased to bloom. 6 to Io feet. June.

LILAC, Ludvig Spaeth-Panicles long, individual flowers large, dark purplish, red, distinct. The finest of its color. 6 to 8 feet. May and June.

LILAC, Madam Lemoine-Undoubtedly one of the best profuse blooming double white lilacs. Always satisfactory. 6 to 8 feet. May and June.

LILAC, Marie LeGrey-Large panicles of single white flowers. One of the finest and best blooming sorts. Very fragrant. 6 to Io feet. May

LILAC, Persian Purple-A more graceful form than some varieties of lilac. The branches are slender, leaves finer and more pointed. Flowers are purple, very fragrant and borne in large panicles. 6 to 8 fet. May and June.

LILAC, Persian White-Similar to the Persian Purple except that the flowers are white. Very good variety. 6 to 8 feet. May and June.

LILAC, Pres. Grevy-Individual flowers of the largest size, very double, trusses large. One of the best blue sorts. 5 to 8 feet. May.

LILAC, Rothomagensis--A grand improvement on the common Persian Lilac. Flowers larger and of reddish purple color, and abundant. Very fragrant. 6 to Io feet. May and June.

LILAC, Tree Villosa-Same as the Villosa but trained in tree form. Very beautiful in the heavy border or for individual planting. Lavender flowers. 8 to 12 feet. May and June.

LILAC, Villosa-A Japanese variety. Flowers are silvery rose and produced in great profusion. A grand distinct type and very satisfactory. 6 to 8 feet. May and June.

MAPLE, Tartarian-A dwarf shrubby tree with handsome finely cut leaves. Good for grouping or planting singly in corners. Attractive clusters of winged seed pods. I5 feet.

PRUNUS, Pissardi-Large shrub or small tree used to color up shrubbery plantings. Its shining purple leaves hold their color well during the summer. 5 to io feet.

PRUNUS, Triloba-A beautiful shrub of medium height, blooming with a great profusion of delicate, pink, rose-like blossoms. Resembles the Flowering Almond but the bush is hardier and larger. Without doubt one of the prettiest shrubs we have. Fine foliage. 6 to 8 feet. May.

PRUNUS, Tomentosa-A white flowering plum. Valuable for its ornamental fruit and foliage. 8 to ro feet. May.

WAYFARING TREE, Viburnum Lantana-Exceedingly interesting with large showy leaves and broad flat flower clusters in white. Can stand full sun. Io to I5 feet. May and June. 
SHEEPBERRY, Viburnum Lentago-Large clusters of cream flowers followed by bluish black fruits. Leaves bronze in spring, orange and scarlet in fall. I5 to 20 feet. May and June.

ARROWWOOD, Viburnum Dentatum-Upright and bushy with an excellent green foliage. Flowers pure white, scarlet berries. 8 to Io feet. May and June.

SNOWBALL, Viburnum Opulus, Sterilis-A splendid ornamental with large, globe-like balls of white flowers. No fruit. Extremely hardy. 6 to 8 feet. May and June.

SNOWBALL, Tree-The same as Viburnum Opulus Sterilis only trained in tree shape, with large spreading crown which presents a beautiful appearance when in bloom. May and June.

SNOWBERRY, White-A rather low growing shrub with small pink flowers, followed by white berries, which hang on until winter. Exceptionally fine foliage. 2 to 4 feet. July and August.

SNOWBERRY, Red-Commonly called Indian currant. Similar to the white except that the fruit hangs in large clusters of bright coral red. 2 to 4 feet. July.

SPIREA, Anthony Waterer-An improved variety of this type, upright grower, large heads of dark crimson flowers. Fine for inside planting. 2 feet. July to October.

SPIREA, Arguta-A Japanese variety of stiff irregular growth and white flowers which appear before the leaves. Foundation or border planting. 4 to 6 feet. April and May.

SPIREA, Billardi-A fine spirea with panicles of bright pink flowers. Medium size, upright grower. Much used in shrub borders. 4 to 5 feet. July and August.

SPIREA, Bumalda-Stiff and upright with new growth tinged with purple. Flowers rosy pink in flattish heads. 2 feet. July to September.

SPIREA, Collosa Alba-Similar in growth and habit to the Anthony Waterer. The blossoms however are pure white. A free and continuous bloomer. 2 feet. June to August.

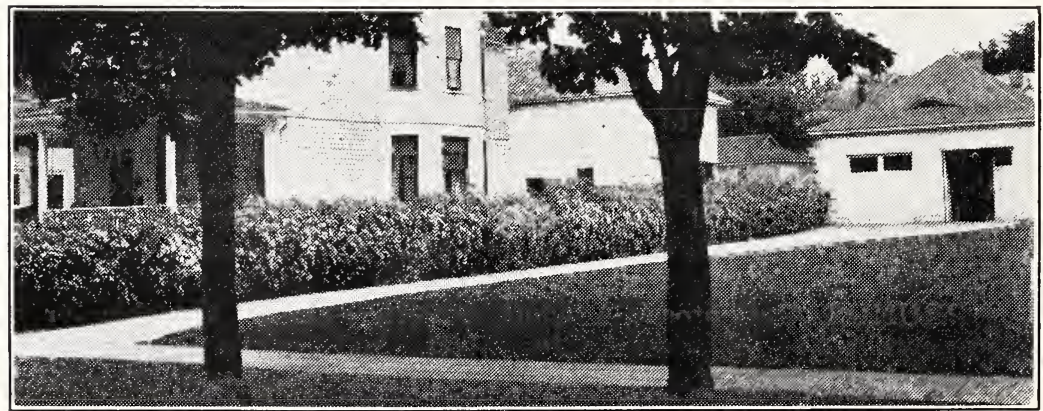

A Spirea Van Houttii Hedge in Bloom 
SPIREA, Collosa Rosea-Flowers pale to deep pink. Unfolding leaves give a rich purplish cast to the whole plant. 3 to 4 feet. June and July.

SPIREA, Collosa Superba-About the same as the Rosea but a stronger bloomer and with brighter foliage. 3 feet. June and July.

SPIREA, Douglasi-Deep rose plumes, used in border or behind lower shrubs about the house foundation. 5 to 7 feet. July and August.

SPIREA, Froebelli-Flowers bright rosy red in flat clusters. Excellent as a border shrub. Foliage turns purple in the fall. 2 to 3 feet. July and August.

SPIREA, Opulifolia-The largest growing species of this group. Valuable for massing and also for background for other shrubs. White flowers. 6 to 8 feet. June.

SPIREA, Opulifolia Aurea-Very much like the former except that the foliage is yellow in spring changing to golden bronze in fall. 6 to 8 feet. June.

SPIREA, Prunifolia-A fine variety with plume-like leaves. Tiny rose-like bloom. Not very hardy and should have winter protection. 4 to 5 feet. April and May.

SPIREA, Sorbifolia-Of a vigorous species with leaves like the Mountain Ash and long elegant spikes of white flowers. 5 to 6 feet. June.

SPIREA, Salicifolia-Long, narrow willow-like leaves. Flowers rose colored. A distinct and very desirable variety. 4 feet. July and August.

SPIREA, Thunbergii-One of the finest spring blooming small shrubs. The flowers are pure white and are borne along the entire length of the branches. 3 to 5 feet. April and May.

SPIREA, Van Houtti-The grandest and most popular of all the Spireas, and as desirable as any shrub in cultivation. White flowers in clusters about an inch in diameter produced freely, almost covering the foliage. Hardy anywhere. Can be used in borders, about the foundation or as a hedge with good effect. 4 to 6 feet. May.

SUMACH, Cut Leaf Staghorn-This shrub is becoming very popular for landscape plantings. It is of spreading habit with large, long, fine cut, lace-like leaves which turn to a beatiful color of gold in fall. Io to 20 feet. June and July.

SUMACH, Dwarf Cut Leaf-Deeply cut leaves, giving the whole shrub a fern-like appearance. Leaves turn bright red in autumn. 3 to 5 feet. July.

SUMACH, Rhus Glabra-A native large growing shrub well adapted for covering barren hills. Very effective for coloring in landscape work, the leaves turning golden hued late in the summer. 8 to 12 feet. July.

SYRINGA, Golden-A compact shrub with bright yellow foliage, very effective as a foliage plant. 4 feet. May and June.

SYRINGA, Grandiflorus-A large and vigorous growing shrub producing an abundance of creamy white flowers of unusual size and fragrance. 6 to io feet. June and July. 
SYRINGA, Lemoine-A showy and free flowing variety with slender arching branches. Flowers creamy white and very fragrant. 5 to 7 feet. May and June.

SYRINGA, Mock Orange-A vigorous growing shrub with sweet scented white flowers in the greatest profusion. Foliage bright and handsome. 8 to io feet. May and June.

TAMARIX - A distinct type of shrub, having leaves somewhat like the Juniper, crowned with delicate pink flowers. Valuable for grouping. 6 to Io feet. July to September.

WEIGELIA, Rosea-Large trumpet shaped, rose colored flowers, are produced so freely that they nearly hide the leaves. Needs winter protection. 4 to 6 feet. May and June.

WEIGELIA, Eva Radke-A remarkably free bloomer. Flowers deep carmine crimson with yellow stamens, quite different from other varieties. Needs winter protection. 4 to 6 feet. All summer.

WEIGELIA, Variegated-A distinct variey having variegated leaves and an abundance of white flowers. 4 to 6 feet. May and June.

\section{Ornamental Hedges}

An ornamental hedge is almost an indispensible factor in building a landscape. It frames the lawn and makes a natural background for all inside planting. On simall grounds the low growing hedges are the most used, while for larger grounds and for screening the higher and more spreading sorts are more adaptable. For hedge purposes the plants should be set one foot apart and pruned severely at planting time.

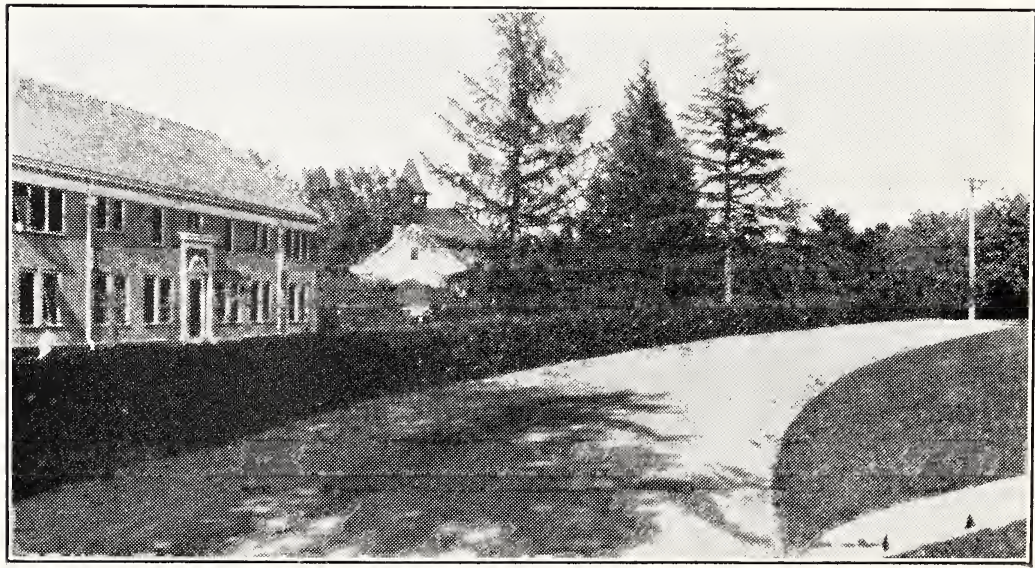

Buckthorn Hedge 
Have the ground fairly rich and stirred to a depth of at least a foot to give the young roots a better chance to start. Keep your hedge free from weeds and grass by cultivating at least a foot on each side. Hedges can be kept at any desired height by trimming, which should be done regularly and at close intervals to induce a heavier growth of foliage near the ground. Hedges where used in place of a fence, unless they are of the flowering type, should be trimmed to maintain a formal appearance. Those listed below are not classed as flowering hedges, but if grown in tree form, are more or less flowering.

AMOOR RIVER PRIVET-The only one of the Privet family that is hardy in the Northwest. Upright in growth, very drought resistant and can be grown in shade. Stands any amount of trimming. When not kept cut bears white flowers followed by bluish-black seeds.

BUFFALO BERRY - A large growing shrub which makes a fine hedge, the effect of the light grey foliage being very striking. Very resistant to drought and winter killing. Has yellow flowers in June, followed by red berries which are edible.

BARBERRY, Thunbergii-This pretty dwarf shrub is used more than any other for ornamental and hedge planting. It is remarkable for its dense spreading growth and attractive appearance. Starts early in the spring and is covered densely with small dainty leaves which color to a brilliant hue in the fall. Large quantities of red berries are produced which hang on throughout the winter, giving a very striking appearance. This variety does not harbor wheat rust and should not be confused with the Purple Leaf Barberry, which is under government quarantine.

BUCKTHORN-Without doubt the most universally known hedge plant grown. Extremely rugged and hardy and stands any amount of pruning. Foliage dense and dark green. Very light bloomer.

BUCKTHORN, Frangula-Similar to above but with more shiny foliage and berries. Perfectly hardy.

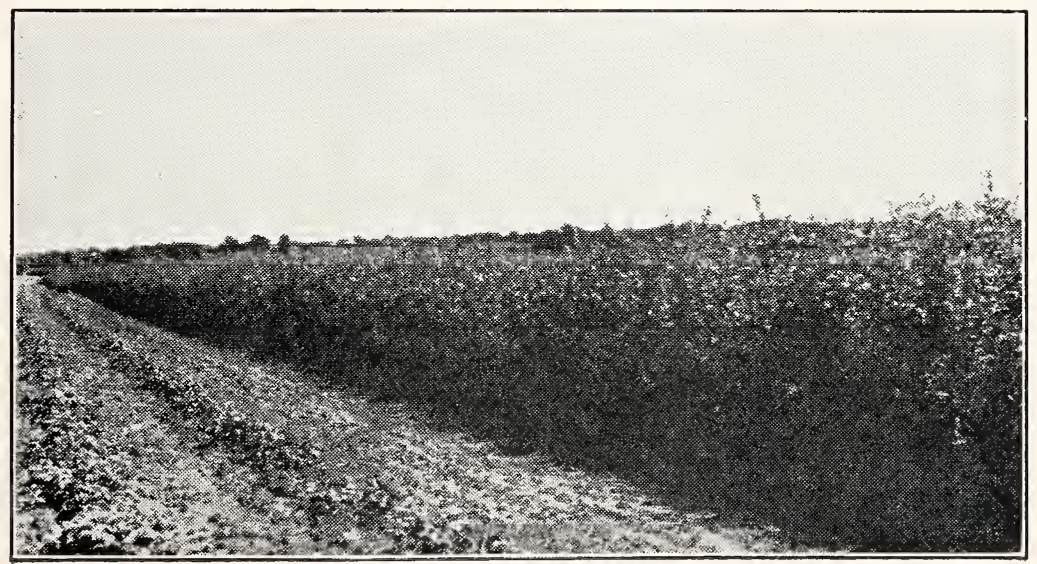

A Row of Caragana 
CARAGANA-Thrives in any well drained soil. Very compact in its growth and desirable for a medium or tall growing hedge. Hardy in the most exposed locations.

RUSSIAN OLIVE-A very large growing shrub. The leaves are narrow and silvery white in color. Stands trimming well, perfectly hardy and easy to grow.

\section{Shade and Ornamental Trees}

ASH, American, White or Green--A native of fine symmetrical outline; valuable for street and park purposes. 'Thrives best in North and South Dakota.

BIRCH, Paper or Canoe-One of the handsomest trees in cultivation and a vigorous grower. When young the bark is dull brown, but changes as the tree grows older to a shiny, silky white, rendering it very attractive.

BIRCH, European, White-A distinct, native species of vigorous, rapid growth. Bark white, leaves triangular, tapering and pointed. It is very hardy and will grow in sandy or rocky soil and in any climate.

BOX ELDER, Ash-Leaved Maple-This species is easily distinguished by the pinnate leaves and greenish-yellow bark. It grows rapidly into a large, spreading tree; found valuable for planting timber claims, shelter belts, etc., in the west where it endures both dought and cold.

CATALPA, Speciosa-Very fine for shade and ornamental purposes; never subject to the attack of insects. Hardy in Southern Minnesota and the South.

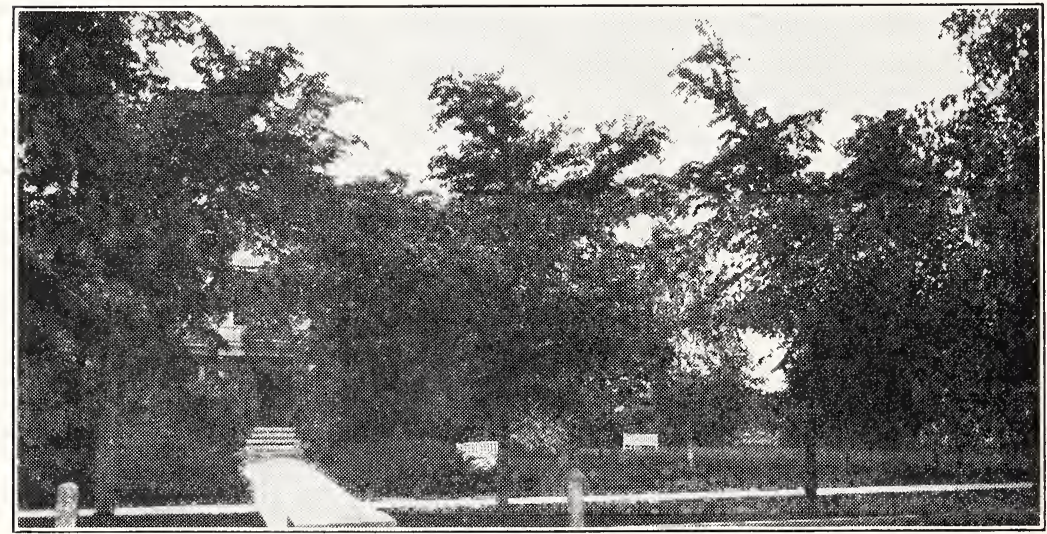

Elm Make a Stately and Effective Boulevard Tree 
ELM, American, White-This is the noble spreading and drooping tree of our own forests. A fast grower, extremely hardy and in every way desirable for street and park planting. The American Elm is the first choice of the experienced landscape designer.

HACKBERRY - A very handsome native tree of rapid growth and great vigor. Bears transplanting well. The character of its growth is similar to the Elm, though the top is not quite so spreading as that variety.

HORSE CHESTNUT or BUCKEYE-This tree has an elegant pyramidal form with large, lobed leaves and showy upright panicles of white flowers. Tree hardy, vigorous and free from insect pests and is among the first trees to unfold its leaves in the spring.

LINDEN, American or Basswood-Rapid growing large sized tree with remarkable straight trunk; deep green, heart-shaped leaves and clusters of fragrant yellow flowers.

LOCUST, Black-Very pretty shade or ornamental tree, with sweet scented flowers in spring. Not overly hardy.

LOCUST, Honey-Tree of very open handsome habit and finely divided foliage. Winter bark brown and olive, while twigs shine as if polished. Hardy.

MAPLE, Norway-A tree of foreign origin; a sturdy and symmetrical grower, forming a broad, spreading rounded head. The leaves are deep green, large and broad, and cling to the branches longer than other sorts.

MAPLE, Sugar or Rock-A valuable native tree for lumber as well as shade and ornamental purposes. It is adaptable to all locations. Roots deeply and grows symmetrically into a tree of large proportions.

MAPLE, Weir's Cut Leaf-A very beautiful silver leaf sort with delicately cut leaves and distinct half-drooping habits. It grows rapidly, forming a straight, upright trunk with slender branches that curve gracefully downward. Very hardy.

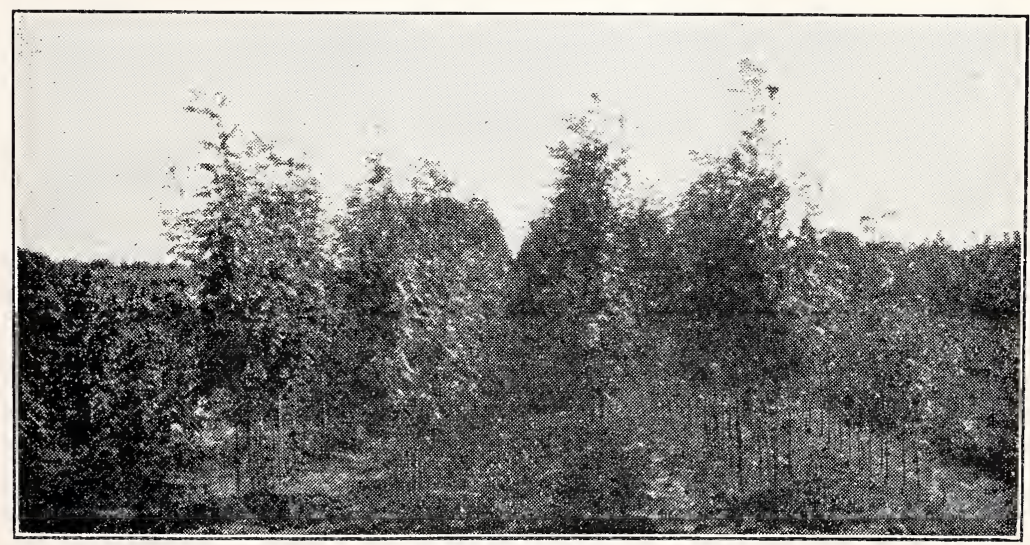

Mountain Ash 
MAPLE, Silver or Soft-A magnificent shade and ornamental tree of rapid growth. It is perfectly hardy and will thrive in any soil and in any locality. The leaves are beautifully shaped and have a silvery gleam. The hardiness and ease of culture of this tree makes it one of the most desirable for street and park planting.

MOUNTAIN ASH, European-A fine, hardy tree; head dense and regular, covered from July to winter with large clusters of bright scarlet berries. Very popular for lawn planting. Hardy in all sections.

MULBERRY, Russian-It is largely planted for sceens and windbreaks, also for shade trees. The fruit, which is rather small, is appreciated by birds and fowls.

OAK, Scarlet-One of the best of the oak family. It forms a fine large tree of vast proportions, the large leathery leaves turning to a fiery scarlet in autumn.

POPLAR, Bolleana-Much like the Lombardy in narrow upright growth. Leaves gracefully cut, light green above and clear white beneath. Very attractive olive-green bark. Very hardy.

POPLAR, Balm of Gilead-A handsome native with thick, dark ovate leaves, silvery beneath. The spicy gum of the buds is used medicinally.

POPLAR, Canadian-A variety of the Russian Poplar which has proven extremely popular on the western prairies. This tree is especially distinguished from the Carolina type by its light green bark and slightly oblong lobed leaves. The best poplar for windbreak purposes.

POPLAR, Cottonwood-A tall native tree with shiny leaves, attaining a height of 80 to 100 feet. Grows rapidly and is very hardy, thriving under most adverse conditions.

POPLAR, Lombardy-Of obelisk form, growing rapidly to extravagant heights. Is much used for screen hedges. Makes a striking feature in any landscape.

POPLAR, Norway-Unexecelled for its quick growth and effect. It outgrows the Cottonwood and is extensively planted where quick groves and windbreaks are desired. This variety is highly recommended by the government to be planted for lumber purposes.

POPLAR, Silver-This is a very beautiful ornamental tree. Leaves white as snow beneath, upper surface green. Extremely hardy, especially adapted to dry upland sections.

POPLAR, Simoni-Similar to the Balm of Gilead and a very rapid grower. Useful for quick growing windbreaks. It has been planted as far north as Manitoba with entire success.

POPLAR, Volga-A new hardy tree from Russia. Of upright growth, similar to the Lombardy, except that leaves are larger and of better form. Branches much stronger. Vigorous and hardy.

WALNUT, Black-A majestic tree, growing to great size; bark rough and dark; foliage beautiful. It does well on most soils and is profitable to plant.

\section{WEEPING ORNAMENTAL TREES}

NIOBE WEEPING WILLOW-A hardy tree with graceful, drooping, golden twigs, very desirable for park or lawn purposes. Well suited to planting anywhere in the northern states. 
WISCONSIN WEEPING WILLOW-A very graceful, rapid growing tree that will stand the cold of almost any climate.

WEEPING MOUNTAIN ASH-A very novel tree in appearance. The branches have a turning and twisting habit which produces a curious effect.

WEEPING MULBERRY-One of the most graceful weeping trees known, forming a perfect umbrella-shaped head with long slender branches drooping to the ground parallel to the stem. Has beautiful foliage, rather small, handsomely cut.

\section{NUT TREES}

We surely owe it to the coming generations, if not to ourselves, to plant liberally of nut bearing trees. Black Walnut lumber, for instance, is now so scarce that the price is almost prohibitive. What better legacy can you leave your children and grandchildren than a fine grove of Black Walnut? In addition to a lumber value increasing yearly, they will soon be producing a fine crop of nuts regularly.

BLACK WALNUT-A native species of great size and majesty. Bark very dark, deeply furrowed, foliage beautiful, nut round. One of the most prized American lumber. Somewhat slow to start but makes good growth after established.

BUTTERNUT-A native tree of medium size, spreading head, reddish colored, dark foliage, very thick. Nut obling and rough.

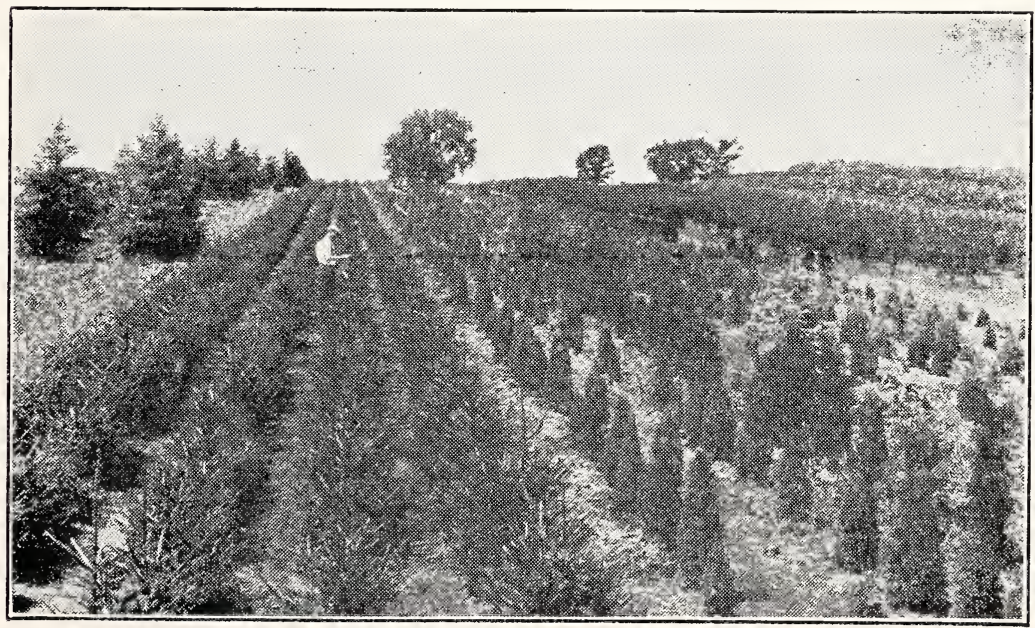

Norway Spruce and Pyramidal Arbor Vitae 


\section{Forest Tree Seedlings}

Where a large number of trees are to be planted, such as for permanent groves or wind-breaks, it is highly advisable to use the seedlings, that is trees not over four to five feet high. They are easier to plant and care for and the cost is but a fraction of what the larger sizes would reach. Before planting a grove or wind-break have ground well enriched and thoroughly worked and dragged smooth as you would for corn. There are many methods of laying out a groove, all of which have their merits, but in general we believe the following to be the one best suited where a large number of seedlings are to be planted.

First mark out your rows the desired distance apart, not less than eight feet, then with a plow run a furrow as deep as possible, throwing the dirt both ways. Next lay the seedlings in the trench with the tops resting on one side, then with one horse, run the plow along the opposite side to throw the dirt back on the roots; next straighten the trees and tramp the dirt firmly around the roots. Follow up

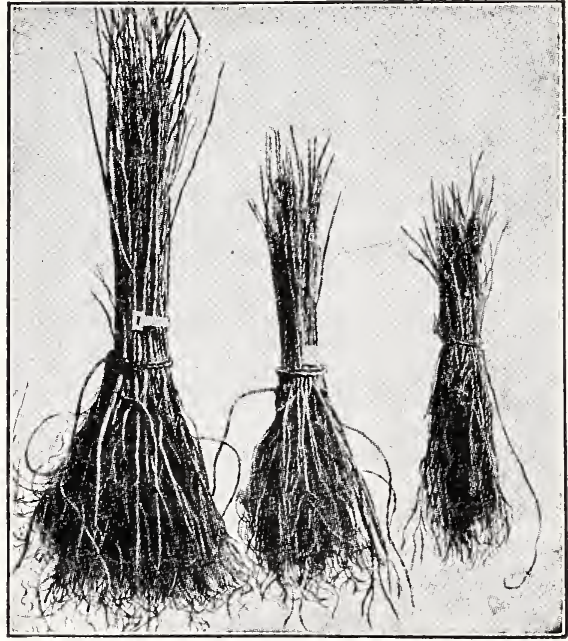

Forest Tree Seedlings on the other side of the

trench and tramp again. This will leave very little earth to throw in by hand The distance apart in the row differs according to the use intended. Willows, where used as a snow hedge, should not be set more than three feet apart in the row and cut back within a foot of the ground. For a grove, such trees as Ash, Elm, Box Elder and Maple are best set at least eight feet and joints broken every second row. With the latter trees many plant a Poplar between each tree in the row. They make a rapid growth and protect the slower growing trees when young. As the permanent grove attains a height of ten to fifteen feet the Poplar can be cut out, giving an abundance of firewood. Keep free from grass and weeds by frequent cultivation and a good mulch around the trees will help retain the moisture during the hot weather in summer. All of the varieties listed as seedlings may be had in larger sizes but are not listed under "Sliade and Ornamental Trees" to avoid duplication.

ASH, American, White or Green-A native of fine symmetrical outline; valuable for street and park purposes. Thrives best in North and South Dakota and Minnesota.

BOX ELDER, Ash-Leaved Maple-This species is easily distinguishd by the pinnate leaves and greenish-yellow bark. It growes rapidly into a large, spreading tree; found valuable for planting timber 
claims, shelter belts, etc., in the West, where is endures both drought and cold.

ELM, American, White-This is the noble spreading and drooping tree of our own forests. A fast grower, extremely hardy and in every way desirable for street and park planting. The American Elm is the first choice of the experienced landscape designer.

MAPLE, Silver or Soft-A magnificent shade and ornamental tree of rapid growth. It is perfectly hardy and will thrive in any soil and in any locality. The leaves are beautifully shaped and have a silvery gleam. The hardiness and ease of culture of this tree makes it one of the most desirable for street and park planting.

POPLAR, Balm of Gilead-A handsome native with thick, dark ovate leaves, silvery beneath. The spicy gum of the buds is used medicinally.

POPLAR, Canadian--A variety of the Russian Poplar which has proven extremely popular on the western prairies. This tree is especially distinguished from the Carolina type by its light green bark and slightly oblong lobed leaves. The best Poplar for windbreak purposes.

POPLAR, Cottonwood-A tall native tree with shiny leaves, attaining a height of 80 to Ioo feet. Grows rapidly and is very hardy, thriving under most adverse conditions.

POPLAR, Lombardy-Of obelisk form, growing rapidly to extravagant heights. Is much used for screen hedges. Makes a striking feature in any landscape.

POPLAR, Norway-Unexcelled for its quick growth and effect. It outgrows the Cottonwood and is extensively planted where quick groves and windbreaks are desired. This variety is highly recommended by the government to be planted for lumber purposes.

POPLAR, Silver-This is a very beautiful ornamental tree. Leaves white as snow beneath, upper surface green. Extremely hardy, especially adapted to dry upland sections.

WILLOW, Golden Russian-A very showy variety, with golden bark of high color, and very showy in winter. Valuable for windbreaks.

WILLOW, Laurel-A handsome, close-growing tree, leaves dark, glossy green and highly ornamental. Extensively planted for a windbreak and hedge purposes.

WILLOW, White-This is the large Willow that has been used so many years for hedges around farms. It does the best in low places.

\section{Evergreens}

In building a landscape Evergreens may be put to so many uses that they are almost an indispensable factor. For a windbreak or shelter belt there is nothing can equal them and for that purpose two or three rows planted on the North and West around the buildings will, in a short time, be very effective in keeping out the cold winter blasts and preventing the snow from piling up in the yard. Plant them eight to ten feet apart in the row and the rows ten feet apart and it is a very good idea to alternate the rows with spruce and pine. The low growing 
kinds, or dwarfs, may be used about the stone or brick foundation walls; to fill in hard angles or soften heavy corners. Plant them always where they have intimate relation to the activities of the home; where they can be seen and felt. In handling and planting never allow the roots to become dry or exposed to the sun or air. Their sap is resinous and once hardened no amount of moisture will dissolve the resin. Dip the roots in thin mud as soon as unpacked and leave them there until the last minute before setting out. Tramp the earth around the roots as firmly as possible and use plenty of water when planting. Remember Evergreens are always in full leaf and evaporation is constantly going on, and unless firmly established when planted the wind will work them loose, destroy the young root hairs and permit the air to get down to the roots. Cultivate once each week until July first, then mulch heavily with straw, lawn clippings or litter to keep the ground moist and cool during July and Angust. Never sprinkle the tops of your Evergreens. Evergreens can be transplanted only in the spring. Specimen Evergreens or large sizes are best shipped balled and burlapped. These trees are dug with a large ball of earth without disturbing the roots in the least and the ball securely wrapped with burlap. When shipped this way they are almost sure to grow. When planting balled and burlapped Evergreens do not remove the burlap from the ball but plant it with the tree and it will soon rot away. Pack the dirt very firmly around the ball and cover the burlap with about two inches of dirt.

ARBOR VITAE, American-The finest evergreen for hedges. It grows rapidly and soon forms a beautiful, dense hedge that is very ornamental. May be trained in any desired shape and stands shearing well.

ARBOR VITAE, Compacta-Dwarf dense little trees with light green foliage, neat and attractive. Useful for beds, borders, cemeteries and low growing hedges.

ARBOR VITAE, Globosa-Of dense, dwarf habit globular in outline. Color a pretty light green. Requires no shearing and is always in good form.

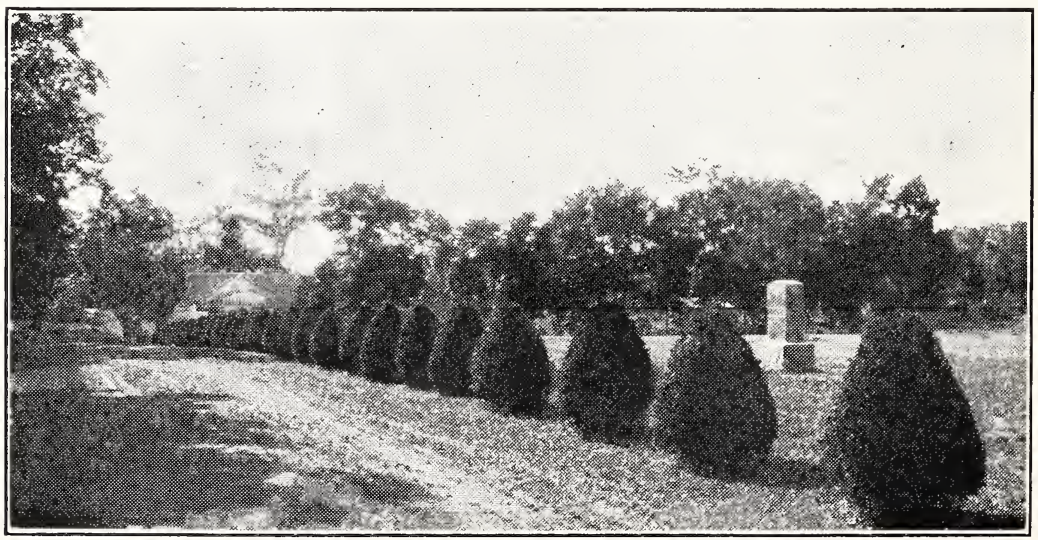

Sheared Arbor Vitae 
ARBOR VITAE, Golden-A beautful variety of compact, globular form, color a lively yellowish green. One of the most handsome.

ARBOR VITAE, Pyramidal-A superb new hardy sort of very compact habit. Grows ten to twelve feet in height and of pyramidal shape. Largely planted in cemeteries where spreading trees would be out of place.

ARBOR VITAE, Siberian-Exceedingly hardy and keeps its color well in winter. Growth compact and globular. Makes an elegant lawn tree and can be trained to shape. Foliage dark green above and bluish beneath.

CEDAR, Red-A native of the North that will stand more rough care than any other evergreen. Leaves similar to Arbor Vitae with reddish tinge. Grows tall and slender and can be used to add formal effect in the garden or planted on hillside to all to the natural beauty. Somewhat subject to fungus.

CEDAR, Silver-A dense pyramidal bush with light, bluish-green foliage, almost silvery white when young, coloring violet in winter.

CEDAR, Platt River Red-One of the best of Cedar family and thoroughly at home in the landscape. Hardy and needs very little care when once started.

FIR, Balsam-A regular symmetrical tree, assuming the conical form even while young. Leaves dark green above, silvery beneath. Very ornamental.

FIR, Concolor--A very beautiful species with silvery gray bark on the voung branches. Leaves long and beautifully silvered, arranged in double rows. Equal in color and beanty to the Colorado Blue Spruce.

FIR, Douglas-A Colorado specie of rapid growth. Makes a large symmetrical tree. Foliage bluish-green. Very dougth resisting and may be planted in dry soils where others cannot survive.

PINE, Austrian or Black-Somewhat slow growing but very dense and compact. Foliage long, dark green. Does well on light soils where there is a fair amount of moisture.

PINE, Mugho-The low, regular, dwarf type of Montana, excellent for foundation planting and with low growing shrubs. Hardy anywhere.

PINE, Ponderosa-Bull pine. A native of the West. The best tree for dry soils but thrives in most any soil. Resembles the Austrian Pine. Extensively planted for windbreaks.

PINE, Scotch-Rapid growing, handsome when young. Often used for windbreaks. Attractive yellow bark. Inclined to raggedness when approaching old age.

PINE, White-The best pine for tall windbreaks. A handsome, graceful, fine-needled American variety with smooth green bark. Very rapid growth. Stands transplanting better than any other pine.

LARCH, European-Like the Cypress it is a desiduous tree bearing cones like evergreens. The foliage is very fine needle-like, appearing earlier in the spring than any other tree and stays until very late fall. The tree is a perfect pyramid in shape and holds it contour until maturity. Very conspicuous on account of its bright green color, unusual needles and branching habit.

JUNIPER, Savin-Being entirely hardy and easy to establish, this is probably the most used among the low growing Junipers. Spreading 
shrub form with slender branches and dark green leaves. Excellent for foundation work and for underplanting.

JUNIPER, Swedish-Columinar growth and very trim. Branches upright and leaves light green. Fine for formal gardens and for cemeteries. Reaches a height of from 8 to ro feet.

JUNIPER, Virginiana-Tapering and symmetrical with bronze foliage in fall and early winter. Perfectly hardy and recommended where large trees are desired. Grows 25 to 30 feet high.

SPRUCE, Black Hills-Compact, shapely and of deep green color. As the name would imply it is a native of the Black Hills, hence naturally adapted to dry weather and high altitudes. Transplants easily and stands severe climatic conditions.

SPRUCE, Colorado Blue-Green type. The queen of ornamental evergreens and especially adapted to northern climates. Foliage varies from light silvery green to as deep a shade as the Norway.

SPRUCE, Colorado Blue-Shiners or Blue type. The same as the green type except in color, which is a rich silvery blue. They are much more rare than the green type, consequently higher priced but their effect in the landscape is wonderfully striking.

SPRUCE, Hemlock-Tree of open pyramidal habit with spreading, irregular branches. Handsome dark green foliage. Very hardy in northern latitudes.

SPRUCE, Norway-The most popular windbreak evergreen. Stands transplanting well and is a fairly rapid grower. Not as satisfactory for ornamental planting as the Black Hills or Colorado, but perfectly hardy in all northern climates.

SPRUCE, White-A very hardy evergreen with deep green foliage similar to the Norway. Compact and upright grower. Succeeds best in northern latitudes.

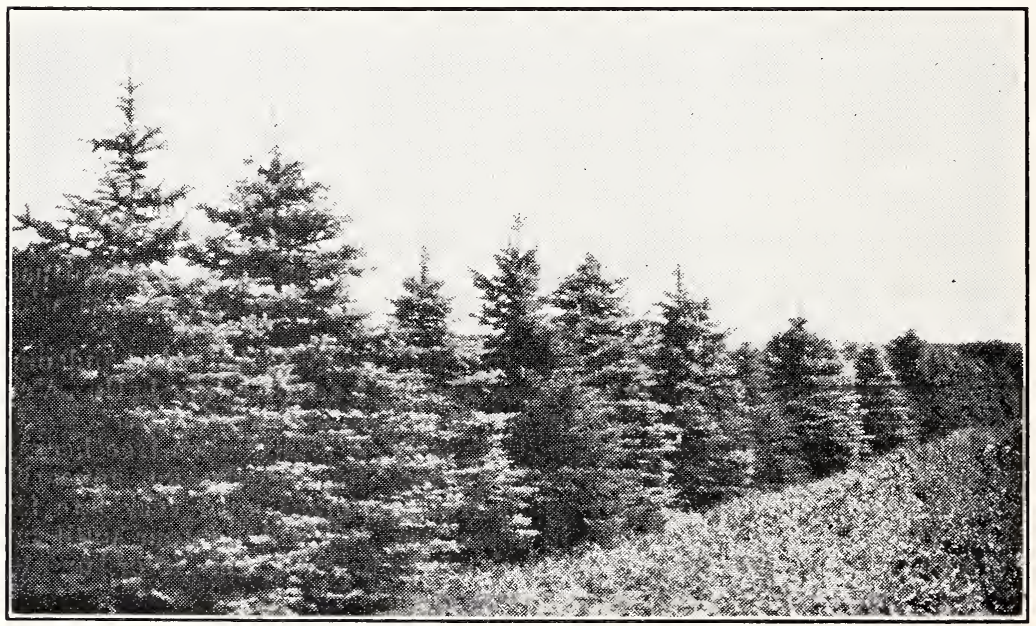

Colorado Blue Spruce, Blue Type 


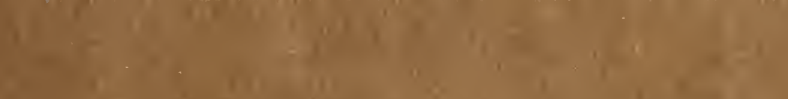

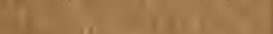




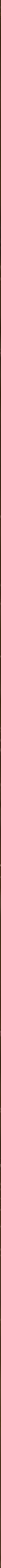

